\title{
Produção de sequência didática com base no gênero infográfico em língua inglesa: um olhar para o processo de transposição didática
}

\author{
Producción de secuencia didáctica con base en el género \\ infográfico en lengua inglesa: una mirada hacia el proceso \\ de transposición didáctica
}

\section{Production of didactic sequence based on the text genre infographic in English language: a look at the didactic transposition process}

Claudia Lopes Pontara ${ }^{1}$

\begin{abstract}
RESUMO: Este trabalho é parte de uma pesquisa de doutoramento cujo objetivo geral consiste em investigar se e em que medida acontece o desenvolvimento de professores de Língua Inglesa da Rede Pública do Estado do Paraná ao participarem de uma Sequência de Formação - SF, alicerçada nos pressupostos teórico-metodológicos do Interacionismo Sociodiscursivo - ISD, no ensino de línguas por meio de gêneros de texto e no procedimento Sequência Didática - SD. Neste artigo, traçamos um paralelo entre a SD elaborada por uma professora participante da SF e as dimensões ensináveis do gênero de texto infográfico, com vistas a analisar como se deu o processo de transposição didática externa do referido gênero e quais indícios de desenvolvimento podem ser percebidos nesse processo de produção docente. Os resultados destacam a importância de que o professor conheça profundamente o gênero de texto com o qual irá trabalhar, para que possa realizar adequadamente o processo de transposição didática. Para tanto, o modelo didático do gênero, bem como a SD com a qual irá conduzir o processo de ensino e aprendizagem são elementos mediadores que podem colaborar com esse processo de entendimento do professor, especialmente, quando ele mesmo os elabora. Essa ação de elaboração de material didático, em nosso caso a SD, sendo constitutiva de um processo mais amplo de formação - a SF pode contribuir para
\end{abstract}

\footnotetext{
${ }^{1}$ Doutoranda do PPGEL- programa de Pós-Graduação em Estudos da Linguagem- Universidade Estadual de Londrina. E-mail: clpontara@gmail.com.
} 
a criação de novas zonas de desenvolvimento proximal no professor participante - fator essencial rumo ao desenvolvimento profissional do docente.

PALAVRAS-CHAVE: Sequência didática. Gênero de texto. Infográfico. Transposição didática. Desenvolvimento profissional.

RESUMEN: Este trabajo es parte de una investigación de doctorado cuyo objetivo general consiste en investigar cómo y en qué medida sucede el desarrollo de profesores de Lengua Inglesa de la Red Pública del Estado de Paraná al participar en una Secuencia de Formación - SF, basada en los presupuestos teórico-metodológicos del Interaccionismo Sociodiscursivo - ISD, en la enseñanza de lenguas por medio de géneros de texto y en el procedimiento Secuencia Didáctica - SD. En este artículo, trazamos un paralelo entre la SD elaborada por una profesora participante de la SF y las dimensiones enseñables del género de texto infográfico, con vistas a analizar cómo se dio el proceso de transposición didáctica externa de dicho género y qué indicios de desarrollo pueden ser percibidos en este proceso de producción docente. Los resultados destacan la importancia de que el profesor conozca profundamente el género de texto con el que va a trabajar, para que pueda realizar adecuadamente el proceso de transposición didáctica. Para ese propósito, el modelo didáctico del género, así como la SD con la que conducirá el proceso de enseñanza y aprendizaje, son elementos mediadores que pueden colaborar con ese proceso de entendimiento del profesor, especialmente, cuando él mismo los elabora. Esta acción de elaboración de material didáctico, en nuestro caso la SD, siendo constitutiva de un proceso más amplio de formación - la SF puede contribuir a la creación de nuevas zonas de desarrollo próximo en el profesor participante - factor esencial hacia el desarrollo profesional del docente.

PALABRAS CLAVE: Secuencia didáctica. Género de texto. Infografía. Transposición didáctica. Desarrollo profesional.

ABSTRACT: This work is part of a PhD research whose general objective is to investigate if and in what extent occurs the development of English Language teachers of Public Schools in the State of Paraná when they participate in an Education Sequence - ES, based on the Sociodiscursive Interactionism - SDI, as well on the teaching of languages through text genres and in the procedure Didactic Sequence - DS. In this article, we draw a parallel between the DS elaborated by a SF participant teacher and the teachable dimensions of the infographics, in order to analyze how the didactic transposition process of this genre occurred and which developmental clues can be perceived in this process of teacher production. The results emphasize the importance that the teacher knows deeply the text genre with which he will work, so that he can properly carry out the process of didactic transposition. For this, the didactic model of the genre, as well as the DS are mediating elements that can collaborate with this process of teacher's understanding, specially when he himself elaborates them. This action of elaboration of didactic material, in our case the DS, being constitutive of a 
broader education sequence - ES, can contribute to the creation of new zones of proximal development in the participating teachers - an essential factor towards the professional development.

KEYWORDS: Didactic sequence. Text genre. Infographic. Didactic transposition. Professional development.

\section{Introdução}

A presença de uma diversidade de gêneros de texto nos livros didáticos de língua inglesa, tanto do ensino fundamental II quanto do ensino médio, tem sido cada vez maior. Podemos notar uma mudança significativa nesse sentido, a partir do primeiro edital do Programa Nacional do Livro Didático - PNLD específico para a língua estrangeira, ocorrido no ano de 2011. Consideramos este um marco no que tange à presença de livros didáticos no processo de ensino e aprendizagem de língua estrangeira (inglês e espanhol) nas escolas públicas. A partir de então, a cada PNLD lançado, os livros vêm trazendo mais e mais gêneros de texto, ampliando as possibilidades de um trabalho diferenciado por parte do professor.

Contudo, para além de reconhecermos os avanços advindos a partir do primeiro PNLD/língua estrangeira, aliados às facilidades de acesso a textos de gêneros diversos ( $e$, em especial de infográficos) na internet, entendemos ser mister que o professor (re)conheça as formas de organização do gênero com o qual irá trabalhar, apropriando-se de tal gênero a partir de quatro planos: plano de ação de linguagem, plano discursivo, plano das propriedades linguísticas e plano das multissemioses.

Este artigo, portanto, trata especificamente do gênero de texto infográfico e o processo de transposição didática externa realizada por uma professora de língua inglesa durante sua participação em uma SF². Nosso objetivo consiste,

\footnotetext{
${ }^{2}$ Conforme exposto em Pontara e Cristovão (2018) uma Sequência de Formação - SF compõe-se das seguintes ações: 1) Revisão da literatura e diagnóstico da realidade; 2) Planejamento, organização e elaboração do material a ser utilizado durante o curso; 3) Oferta do curso e posterior implementação dos
} 
portanto, em identificar as aproximações e/ou os distanciamentos entre os elementos ensináveis do gênero infográfico e duas versões da SD (a primeira e a última) elaboradas pela referida professora, além de suscitar discussões acerca das possibilidades de desenvolvimento da docente em questão.

Dividimos este artigo em cinco seções, incluindo a introdução. Na Seção 1 , apresentamos os referenciais de base que subsidiam nossas discussões, a saber, o Interacionismo Sociodiscursivo - ISD (BRONCKART, 2006, 2007, 2008, 2012; CRISTOVÃO, 2011; MACHADO, 2005), o ensino de línguas com base em gêneros de texto por meio do procedimento Sequência Didática - SD (CRISTOVÃO， 2013; CRISTOVÃO， STUTZ， 2011; DOLZ， NOVERRAZ, SCHNEUWLY, 2010), transposição didática (CHEVALLARD, 1989; MACHADO; CRISTOVÃO, 2006), modelo didático do gênero (SCHNEUWLY; DOLZ, 2010) /modelo teórico do gênero (BARROS, 2012); mediação e desenvolvimento docente (BRONCKART, 2013; OLIVEIRA, 1997; STETSENKO, 2016; VIANNA; STETSENKO, 2006; VYGOTSKY, 1978). Expomos, na Seção 2, o nosso percurso metodológico, seguido da Seção 3, em que apresentamos e discutimos nossos resultados de análises referentes ao gênero de texto infográfico (AL HOSNI, 2016; DIONÍSIO, 2013; GONÇALVES; ROSOLEM, 2018; KANNO, 2013; TEIXEIRA, 2010) e à SD elaborada pela professora foco deste estudo. Finalmente, concluímos com algumas considerações acerca de todo esse processo.

materiais produzidos durante sua realização; 4) Realização de sessões de autoconfrontação; 5) Análises dos resultados obtidos ao longo do processo da SF. 


\section{Aportes Teóricos}

\section{O interacionismo sociodiscursivo em alguns conceitos}

O ISD postula que os processos de construção do sujeito, bem como os processos de construção social e cultural, são indissociáveis do processo de desenvolvimento humano, enfatizando o estudo da língua como um instrumento de interação social por meio de uma prática viabilizada pelos gêneros de texto. (BRONCKART, 2007).

Bronckart (2012) assevera que a linguagem, sendo constitutiva das atividades sociais (gerais) do ser humano, apresenta-se como estritamente relacionada a essas. A atividade social, portanto, como fenômeno coletivo, demanda a atividade de linguagem, tendo os "gêneros como verdadeiras ferramentas semióticas complexas, que permitem que realizemos ações de linguagem, participando das atividades sociais de linguagem" (SCHNEUWLY, 1994 apud MACHADO, 2005, p. 251).

Em relação aos termos "atividade" e "ação", embora se refiram a uma leitura do agir que envolvem dimensões motivacionais e intencionais, ambos se diferem no nível de mobilização (BRONCKART, 2008). Ou seja, a ação designa uma leitura do agir no nível das pessoas em particular (um só actante) denominada de ações singulares. Em contrapartida, a atividade marca um agir no nível coletivo. Por sua vez, o termo "agir" é definido pelo ISD como "[...] qualquer forma de intervenção orientada de um ou de vários seres humanos", (BRONCKART, 2008, p. 120), envolvendo, por conseguinte, os termos "actante", "ator" e "agente".

Bronckart (2008) apresenta-nos, ainda, o que poderia vir a impulsionar um agir, a partir do que ele denomina de plano motivacional, plano dos recursos e plano da intencionalidade, dando origem aos termos: motivos, capacidades, intenções, finalidades, instrumentos e determinantes externos. O autor expõe que o agir, ao referir-se a uma pessoa em particular (a ação), tem no plano 
motivacional, os motivos, os quais consistem nas razões interiorizadas pelo indivíduo; no plano de intencionalidade, as intenções - tidas como fins do agir; no plano dos recursos, as capacidades - recursos atribuídos a uma pessoa, sejam eles mentais ou comportamentais. Referindo-se a um coletivo (a atividade), apresenta no plano motivacional, os determinantes externos, podendo ser de natureza material ou das representações; no plano da intencionalidade contempla as finalidades, as quais são socialmente validadas; no plano dos recursos, os instrumentos.

A Figura 1 procura sintetizar os conceitos anteriormente abordados com relação ao agir:

Figura 1 - Elementos do agir

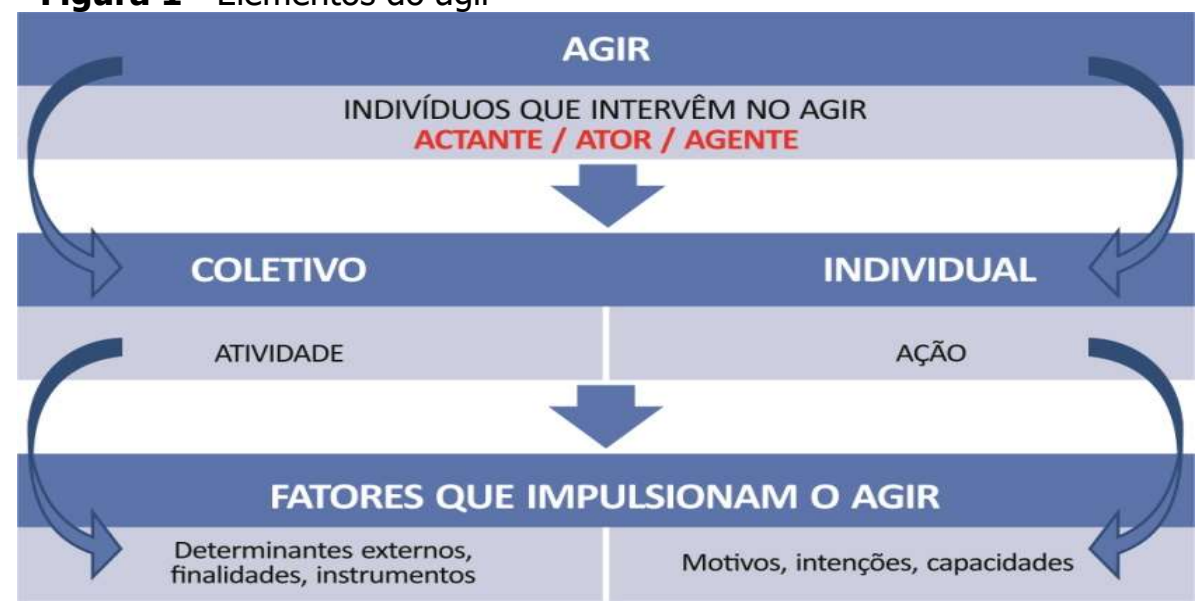

Fonte: a autora.

Trazemos, ainda, algumas considerações acerca dos termos actante/ ator/agente, os quais, envolvidos em um agir, assumem papéis ora mais, ora menos protagonizantes do agir de que participam. Assim, um actante seria todo e qualquer indivíduo envolvido em um agir, ao passo que ator e agente representam polos diferentes. Um ator apresenta-se como aquele indivíduo tido como fonte de todo um processo e, portanto, dotado de capacidades, motivos, intenções. $O$ agente, por outro lado, participa também de um agir, contudo, não consegue, por razões várias, se estabelecer como alguém que age a partir de / com / devido a seus motivos/suas intenções/suas capacidades. Ou seja, todo ator 
e agente é também um actante; mas, nem todo actante se firma como ator, podendo então, participar de ações/atividades como um mero agente.

Assim, temos que uma atividade de linguagem, efetivada com e a partir de uma atividade geral, em um contexto socialmente construído, necessariamente inclui nesse processo, os textos - produtos concretos da atividade de linguagem, os quais são definidos por Bronckart (2008, p. 113) como "correspondentes empíricos das atividades linguageiras, produzidos com os recursos de uma língua natural". Isso nos leva a afirmar que não há atividade de linguagem sem textos, os quais, por sua vez, se encontram no que Bronckart (2012, p. 101) denomina de nebulosa de gêneros, constituindo "um reservatório de modelos textuais". Ao utilizar o termo "nebulosa", Bronckart (2012) traz à tona uma analogia com a intenção de retratar a dificuldade de se categorizar/classificar os gêneros de maneira definitiva, com base em critérios pré-estabelecidos e sem relação com o contexto social, pois, segundo o próprio autor, os gêneros passam por constantes mudanças:

[...] os gêneros de textos continuam sendo entidades profundamente vagas; as múltiplas classificações existentes são divergentes e parciais e nenhuma delas pode ser considerada como um modelo de referência estabilizado e coerente. (BRONCKART, 2012, p. 73).

A escolha do gênero a ser empregado em uma dada situação de ação de linguagem constitui-se, pois, na mais geral das decisões por parte de um actante.

Nessa perspectiva, tratamos, a seguir de aspectos teórico-metodológicos acerca do processo de ensino e aprendizagem de línguas com base em gêneros.

\section{0 ensino com base em gêneros de texto e a transposição didática}

Entendemos que, para os gêneros tornarem-se mediadores, transformadores da atividade e/ou da ação, é necessário que sejam apropriados pelo sujeito, passando dessa forma, do estatuto de artefato para o de instrumento. Assim, ao mesmo tempo em que o gênero pode entrar na sala de 
aula como um instrumento que medeia "toda estratégia de ensino e o material de trabalho, [...] fornecendo um suporte para a atividade, nas situações de comunicação, e uma referência para os aprendizes" (DOLZ; SCHNEUWLY, 2010, p. 44), ele também pode vir a ser, nesse mesmo processo, um objeto de ensino e aprendizagem. $E$, como tal, o gênero demanda ações sistematizadas por parte do professor, levando os educandos à sua apropriação, possibilitando-lhes realizar ações de e com a linguagem, mediante o desenvolvimento de suas capacidades de linguagem (de significação, de ação, discursivas, linguísticodiscursivas, multissemióticas).

Considerando, portanto, que o ISD constitui-se em uma teoria que se debruça também sobre aspectos metodológicos relacionados ao ensino de línguas, Bronckart (2006) afirma que realizar a transposição didática dos modelos teóricos e das pesquisas empíricas tem sido um desafio para os professores ao se depararem com documentos oficiais que sinalizam, por exemplo, para um ensino com base em gêneros. Nesse sentido, de acordo com Cristovão (2010), o procedimento SD constitui-se na proposta do ISD para esse ensino com base em gêneros, confirmando a afirmação de que nossa escolha por tal aporte teórico se deu tendo em vista a nossa preocupação com o efetivo processo de ensino e aprendizagem de línguas nos contextos da Educação Básica (Ensino Fundamental II e Ensino Médio) das escolas públicas do estado do Paraná.

Os autores genebrinos Dolz, Noverraz e Schneuwly (2010, p. 82) definem uma SD como "[...] um conjunto de atividades escolares organizadas, de maneira sistemática, em torno de um gênero textual oral ou escrito", cujo objetivo é ajudar o aluno a dominar um gênero de texto, possibilitando-lhe escrever e/ou falar de uma maneira mais apropriada em uma situação de comunicação. Para tanto, a elaboração de uma SD deve partir de uma estrutura de base, conforme definido pelo grupo de pesquisadores de Genebra. Tal estrutura se configura em etapas assim denominadas: a) apresentação da situação; b) produção inicial; c) módulos necessários, de acordo com as necessidades de aprendizagem de uma determinada turma de alunos e d) produção final. 
Bronckart (2012), por sua vez, afirma não haver possibilidade de uma transposição direta de concepções teóricas ao campo prático, pois qualquer intervenção didática implica na consideração da situação de ensino de uma matéria (disciplina), ou seja, da história de onde ela provém, assim como na consideração das restrições do sistema escolar em que essa situação se insere.

Com isso, reportamo-nos à questão da transposição didática. Chevallard, um dos estudiosos sobre transposição didática, menciona que "o ensino nunca foi uma atividade fácil e natural e que gostaria de saber o que leva as pessoas a não enxergarem isto" (CHEVALLARD, 1989, p. 6, tradução nossa) ${ }^{3}$. Corroborando o pensamento do educador francês, entendemos como altamente complexo 0 trabalho que envolve o processo de ensino.

Nessa perspectiva, realizar a transposição didática requer ações que, de acordo com Machado e Cristovão (2006), constituem-se em três níveis básicos de transformações: I) Conhecimentos científicos; II) Conhecimentos a serem ensinados; III) Conhecimentos efetivamente ensinados e aprendidos; os quais estão inseridos, de acordo com Chevallard (1985 apud STUTZ, 2012) no nível externo e interno de transposição, conforme apontado na Figura 2:

Figura 2 - Níveis da transposição didática

\footnotetext{
${ }^{3}$ But teaching has never been an easy and natural business. I shall consider a little further on why so many people simply do not see things in this way.
} 


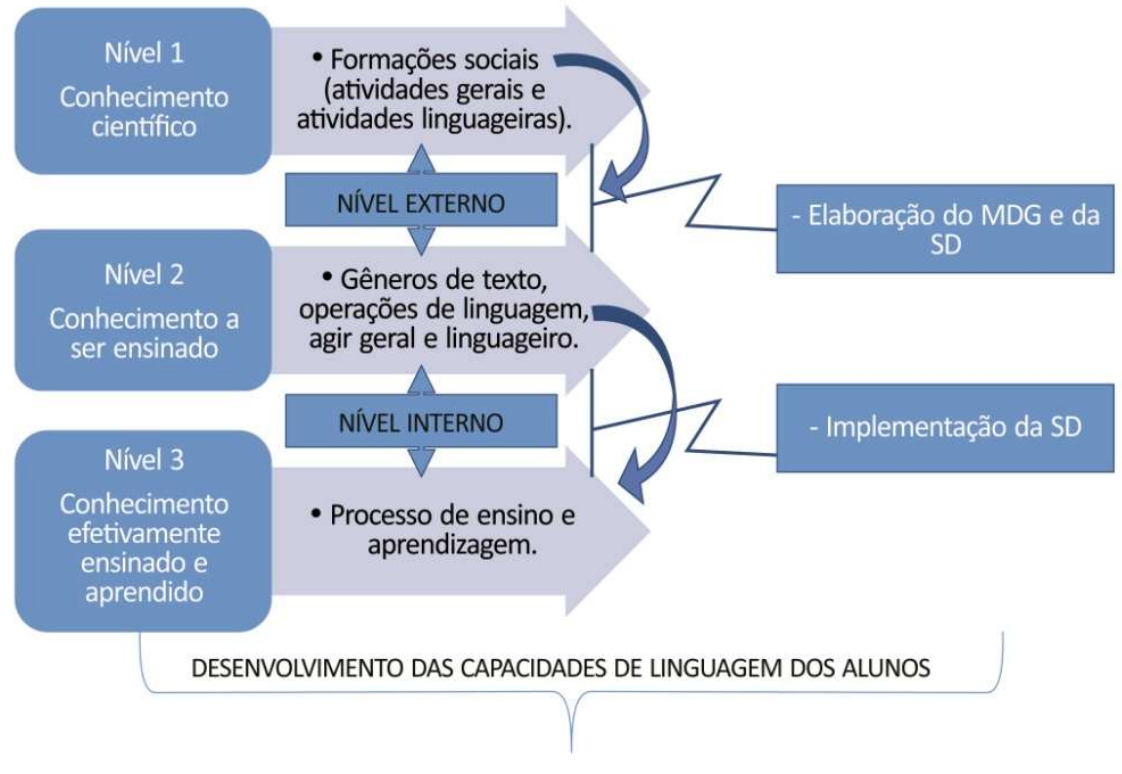

Fonte: a autora.

Assim, temos que o nível externo de transposição compreende a transição dos conhecimentos científicos a conhecimentos a serem ensinados e "parte dos objetos do saber úteis fora da instituição escolar para constituir novos objetos escolares, mais eficazes, porque mais significativos para os alunos" (NASCIMENTO, 2010, p. 1233). Nesse nível, ainda, de acordo com Stutz (2012), encontram-se as instruções oficiais, os planos de ensino, os materiais didáticos, os quais estabelecem relação com os saberes científicos a serem didatizados.

A transposição dada no nível interno estabelece ligação com o conhecimento a ser ensinado e o conhecimento efetivamente ensinado e apropriado. A relação se estabelece com o conhecimento a ser ensinado no momento em que aqueles conhecimentos iniciais (científicos) passam pela transposição externa, configurando-se, em nosso caso, no Modelo Didático de Gênero - MDG e na SD, que, tomando o gênero como instrumento e objeto de ensino, tem como objetivo maior desenvolver as capacidades de linguagem - $\mathrm{CL}$ dos alunos durante todo o processo de ensino e aprendizagem gerado pela implementação da SD elaborada pela professora participante deste estudo. 
Para este artigo, nos deteremos no nível externo da transposição didática, o qual envolve: A) a elaboração do $\mathrm{MDG}^{4}$ e B) elaboração da SD, realizando a transposição dos conteúdos científicos a conteúdos ensináveis.

Com relação à elaboração do MDG, Schneuwly e Dolz (2010) esclarecem que esse processo envolve: I) conhecer o estado da arte sobre o gênero a ser didatizado, o que inclui também suas características linguístico-discursivas; II) ter conhecimento das possíveis capacidades e dificuldades dos alunos a quem a SD se destina, além do que preconizam os documentos oficiais quanto às orientações de ensino e aprendizagem para a língua em questão; III) possibilitar que os saberes didatizados estejam coerentes com os objetivos propostos.

Como uma ampliação ao proposto pelos autores genebrinos, Barros (2012) apresenta em sua Tese de Doutorado o que ela denomina de Dispositivo Didático para a Modelização do Gênero. Fazendo uma associação com as CL (Capacidades de Ação - CA, Capacidades Discursivas - CD, Capacidades Linguístico-Discursivas - CLD) a pesquisadora faz questionamentos que visam orientar o professor durante o processo de estudo de um dado gênero a fim de elaborar o seu MDG.

Tendo em consideração o fato de que o objetivo maior do ensino de línguas (adicionais ou materna) é o desenvolvimento das CL dos alunos, acrescentamos, às três capacidades originalmente apresentadas pelo grupo de Genebra, as Capacidades de Significação-CS (CRISTOVÃO; STUTZ, 2011; CRISTOVÃO, 2013), bem como as Capacidades Multissemióticas - CMS (LENHARO, 2016).

Quanto às CMS, Lenharo (2016), em sua Dissertação de Mestrado apresenta os critérios relacionados a tais capacidades com base em palestra proferida por Dolz (2015), quando o pesquisador trata da questão da avaliação de textos na escola, como podemos observar na Figura 3:

Figura 3 - Palestra proferida pelo pesquisador Joaquim Dolz

\footnotetext{
${ }^{4}$ De acordo com De Pietro et al. (1996, 1997 apud CRISTOVÃO, 2007, p. vii), o MDG constitui "um objeto descritivo e operacional, construído para aprender o fenômeno complexo da aprendizagem de um gênero".
} 


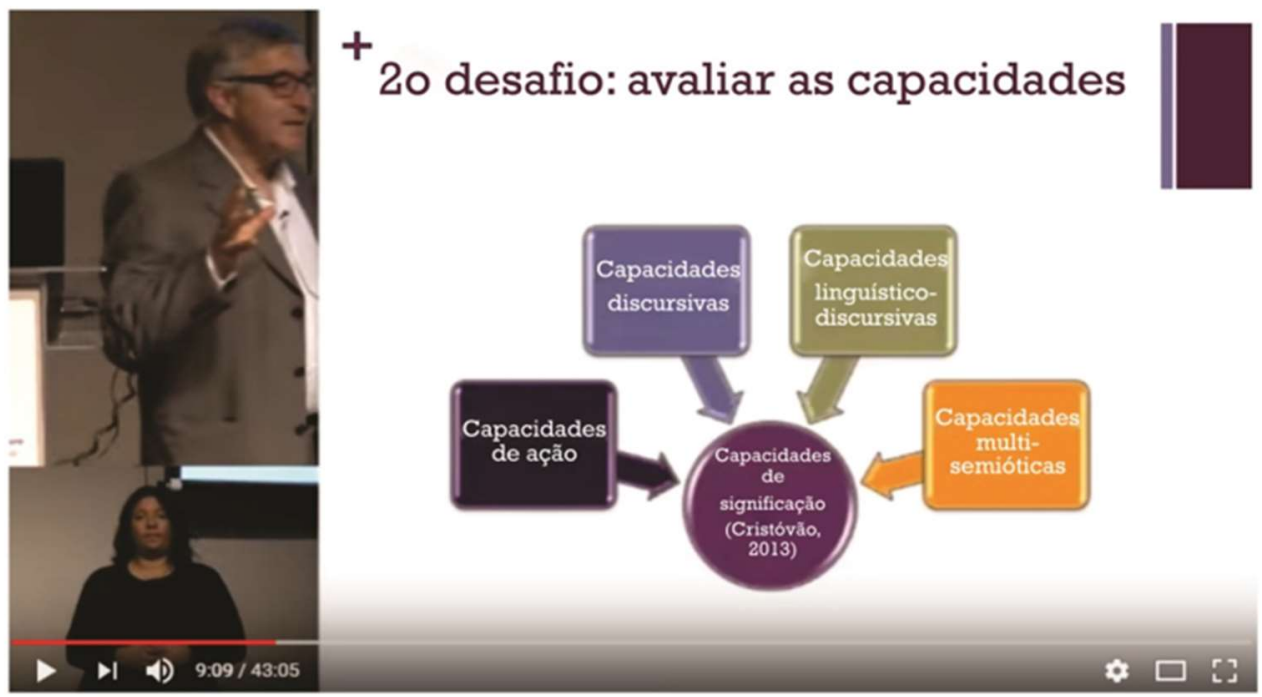

Fonte: Dolz (2015).

O pesquisador, ao citar as CS, esclarece que são elas as responsáveis por reunir todas as demais capacidades, de modo a atribuir significados coerentes e coesos aos textos singulares dos alunos relacionando-os ao contexto macro em que se inserem. Embora tenha assinalado em seus slides para a necessidade de tratar também das CMS, o autor não apresenta maiores detalhes. Contudo, levando em consideração o fato de que nosso estudo envolve um gênero de texto marcadamente multimodal, entendemos, assim como Lenharo (2016, p. 30), que "tais capacidades desempenham papel central quando da análise de textos que apresentam materialidades sonoras, digitais e visuais".

Isto posto, apresentamos a seguir, um quadro com base em Barros (2012) cujo intuito seja, tal como a autora já indicou, direcionar o processo de modelização de um gênero. Entretanto, trazemos adaptações ao quadro original, inserindo inclusive, critérios relacionados às Capacidades de Significação - CS, bem como às Capacidades Multissemióticas - CMS.

Conforme exposto, segue o Quadro 1:

Quadro1 - Dispositivo orientador para modelização do gênero 


\begin{tabular}{|c|c|}
\hline \multicolumn{2}{|c|}{ DISPOSITIVO ORIENTADOR PARA MODELIZAÇÃO DO GÊNERO } \\
\hline $\begin{array}{l}\text { CAPACIDADES DE } \\
\text { LINGUAGEM }\end{array}$ & QUESTÕES NORTEADORAS PARA A ANÁLISE \\
\hline $\begin{array}{l}\text { CAPACIDADES DE ACCÃO } \\
\text { (Contexto imediato da } \\
\text { situação de linguagem) }\end{array}$ & $\begin{array}{l}\text { 1. A que prática social o gênero está vinculado? } \\
\text { 2. É um gênero oral ou escrito? } \\
\text { 3. A qual esfera de comunicação pertence? } \\
\text { 4. Quais as características gerais dessa esfera? } \\
\text { 5. Quem produz esse gênero (emissor)? } \\
\text { 6. Para quem se dirige? (destinatário)? } \\
\text { 7. Qual o papel discursivo do emissor? } \\
\text { 8. Qual o papel discursivo do destinatário? } \\
\text { 9. Com que finalidade/objetivo produz o texto? } \\
\text { 10. Sobre o que (tema) os textos desse gênero tratam? } \\
\text { 11. Qual é a relação estabelecida entre o produtor e o } \\
\text { destinatário? Afetiva? Comercial? } \\
\text { 12. Qual o valor desse gênero na sociedade? } \\
\text { 13. Quais podem ser os suportes desse gênero? } \\
\text { 14. Qual meio de circulação (onde o gênero circula)? } \\
\text { 15. Qual o tom do texto (mais descontraído, humorístico, } \\
\text { objetivo, poético, coloquial, sisudo, familiar, moralista, de } \\
\text { poder )? }\end{array}$ \\
\hline $\begin{array}{l}\text { CAPACIDADES DE } \\
\text { SIGNIFICAÇÃO } \\
\text { (Contexto mais amplo da } \\
\text { situação de linguagem - } \\
\text { ideológico, histórico, } \\
\text { sociolcultural, econômico, } \\
\text { etc.) }\end{array}$ & $\begin{array}{l}\text { 1. Que relações podem ser estabelecidas entre textos desse } \\
\text { gênero e a forma de ser, pensar, agir e sentir de quem os } \\
\text { produz? } \\
\text { 2. Que mapas semânticos podem ser construídos com base } \\
\text { em textos desse gênero? O que esses mapas semânticos } \\
\text { podem revelar? } \\
\text { 3. Que atividades praxiológicas podem dar origem a textos } \\
\text { desse gênero? } \\
\text { 4. Qual a sócio-história do gênero? } \\
\text { 5. Que relações podem ser estabelecidas entre textos desse } \\
\text { gênero e o contexto social mais amplo? } \\
\text { 6. Quais vozes são frequentes em textos desse gênero (do } \\
\text { autor, sociais, de personagens)? } \\
\text { 7. De que instâncias advêm essas vozes (do poder público, } \\
\text { do senso comum, de autoridades científicas)? } \\
\text { 8. Como essas vozes se relacionam com o contexto em que } \\
\text { o texto se insere? }\end{array}$ \\
\hline $\begin{array}{l}\text { CAPACIDADES } \\
\text { MULTISSEMIOTICAS } \\
\text { (Diferentes semioses que se } \\
\text { materializam em todos os } \\
\text { elementos não-verbais.) }\end{array}$ & $\begin{array}{l}\text { 1. Como os elementos não-verbais do gênero se relacionam } \\
\text { com os elementos verbais? } \\
\text { 2. As cores, as imagens, os sons se constituem como } \\
\text { elementos essenciais à constituição do texto? } \\
\text { 3. Os elementos não verbais ajudam a construir o(s) } \\
\text { sentidos(s) do texto? } \\
\text { 4. As palavras são grafadas com tipografia/cores } \\
\text { diferenciadas? } \\
\text { 5. Há mobilização de elementos paratextuais (quadros, } \\
\text { imagens, cores...) ou supratextuais (títulos, subtítulo, } \\
\text { sublinhado...)? Como esses elementos agem na construção de } \\
\text { sentidos do texto? }\end{array}$ \\
\hline
\end{tabular}




\begin{tabular}{|c|c|}
\hline \begin{tabular}{l}
\multicolumn{2}{c}{ CAPACIDADES } \\
DISCURSIVAS \\
$\begin{array}{l}\text { (Organização } \\
\text { infraestrutura geral do } \\
\text { texto) }\end{array}$
\end{tabular} & $\begin{array}{l}\text { 1. Qual o tipo de discurso (expor ou narrar)? } \\
\text { 2. É um expor interativo (escrito em 1ã pessoa, se reporta } \\
\text { explicitamente ao interlocutor, tenta manter um diálogo } \\
\text { mais próximo com o interlocutor, explicita o tempo/espaço } \\
\text { da produção)? } \\
\text { 3. É um expor teórico (não deixa marcas de quem fala, } \\
\text { para quem fala, de onde e quando fala)? } \\
\text { 4. É um narrar ficcional? } \\
\text { 5. É um relato (narrar acontecimento vivido)? } \\
\text { 6. Como é a estrutura geral do texto? Qual a sua cara? } \\
\text { Como ele se configura? É dividido em partes? Tem } \\
\text { título/subtítulo? É assinado? Qual sua extensão } \\
\text { aproximada? Acompanha fotos/figuras? } \\
\text { 7. Como são organizados os conteúdos no texto? Em forma } \\
\text { de lista, versos, prosa? } \\
\text { 8. Qual o tipo de sequência predominante (narrativa, } \\
\text { injuntiva, descritiva, explicativa, argumentativa, dialogal)? } \\
\text { 9. Há expressão gestual, facial, entonação, pausas? }\end{array}$ \\
\hline $\begin{array}{l}\text { CAPACIDADES } \\
\text { UNGUISTICO } \\
\text { DISCURSIVAS } \\
\\
\text { (Unidades linguisticas } \\
\text { implicadas na compreensão } \\
\text { e produção de um texto) }\end{array}$ & $\begin{array}{l}\text { 1. Como são feitas as retomadas textuais (mais por } \\
\text { pronomes ou nomes)? Quais são as estratégias mais } \\
\text { usadas? Substituições ou sinônimos? Por termos genéricos / } \\
\text { específicos? Por nominalizaçães? Por repetições? Qual o } \\
\text { grau de afetividade / valoração expresso pelas retomadas? } \\
\text { 2. Como é feita a coesão verbal? Quais os tempos verbais } \\
\text { usados? } \\
\text { 3. Quais os tipos de conectivos usados (lógicos, espaciais, } \\
\text { temporais)? } \\
\text { 4. Qual a variedade linguística privilegiada (mais formal, } \\
\text { mais informal, coloquial, estereotipada)? } \\
\text { 5. Respeita a norma culta da língua? Usa gírias? } \\
\text { 6. Como se dá a escolha lexical? Há mais substantivos } \\
\text { concretos, abstratos? Há muitos verbos de ação, de } \\
\text { estado? Há muitos adjetivos? Que tipo de adjetivos } \\
\text { (objetivos, subjetivos, afetivos, físicos, superlativos, } \\
\text { comparativos)? } \\
\text { 7. Como são mobilizados os sinais de pontuação no texto? } \\
\text { Quais os mais usados? E com que finalidade? } \\
\text { 8. Há uso de figuras de linguagem? Quais? } \\
\text { 9. Há rimas? Que tipo de rima? } \\
\text { 10. Há mobilização de discurso direto, indireto? Quais os } \\
\text { recursos linguísticos/gráficos empreados (aspas, } \\
\text { travessão, dois pontos)? }\end{array}$ \\
\hline
\end{tabular}

Fonte: a autora, com base em Barros (2012).

Entendemos ser essencial esse processo de estudo do gênero por parte do professor. Passar pelo momento de elaborar o MDG ajuda o docente a compreender melhor quais objetivos guiarão o seu trabalho ao propor um ensino com base em um gênero, seja ele qual for. Identificar os elementos ensináveis do gênero, sua função social e como ele poderá ser trazido para a sala de aula com vistas a propor um agir linguageiro assim como um agir geral é fundamental para que não se gramaticalize o ensino de gêneros. Dito de outra forma, é preciso que o professor de fato se aproprie dos gêneros que se propõe a ensinar, de modo a se tornar um mediador em sala de aula, dotado de saberes e capacidades que venham a contribuir com o processo de desenvolvimento dos alunos. 
Contudo, não podemos deixar de levar em consideração todo um contexto de trabalho a que o professor é submetido, a saber: várias turmas, muitos alunos por turma, obrigatoriedade de aplicação de infinitos instrumentos de avaliação e recuperação, aulas em mais de uma escola, hora-atividade insuficiente, dentre outros fatores. Diante desse contexto real de trabalho, não podemos deixar de ponderar também sobre as reais condições que o professor possui para elaborar o seu próprio MDG para cada gênero de texto que consta em seu plano de ensino. Assim, com o intuito de colaborar com o docente que se propõe a ministrar suas aulas com base em gêneros, defendemos, com base em Barros (2012), a existência de uma fase anterior à elaboração do MDG, denominada pela autora como Modelo Teórico do Gênero - MTG.

O MTG, assim como definido pela pesquisadora, é elaborado de maneira genérica, sem levar em conta o contexto de ensino no qual será implementada a SD. Assim, um MTG apresenta as vozes dos especialistas acerca do que já se estudou sobre o gênero, bem como possíveis dimensões ensináveis do gênero relacionadas às $\mathrm{CL}$. A partir dessa modelização, o trabalho do professor poderá se tornar menos custoso, demandando um tempo menor para que ele elabore o seu MDG, destinado especificamente às turmas com as quais irá trabalhar.

A despeito de advogarmos em favor dessa fase anterior à fase de elaboração do MDG, em nossa pesquisa de doutorado, os professores que participaram da SF não tiveram a oportunidade de se utilizarem desse dispositivo didático ao elaborarem o MDG que nortearia a elaboração de suas SD. E, embora os participantes estivessem envolvidos em um curso de 40 horas, com encontros presenciais, ficou evidenciado que as condições de trabalho anteriormente mencionadas, de fato impactam negativamente no processo de formação continuada do professor. E não somente isso, impactam também em seu processo de preparação e planejamento das aulas.

Nossas análises demonstrarão que a SD foco deste estudo deixou de contemplar algumas dimensões importantes na constituição do gênero infográfico. Identificamos, portanto, uma falha no momento de elaboração do 
MDG, talvez ocorrida devido ao pouco tempo disponível por seus elaboradores ou até mesmo pela inexperiência na elaboração de tal dispositivo. Isso ratifica a nossa defesa de que a existência de um MTG poderia contribuir com esse processo.

Os elementos que impulsionam o agir, sejam eles voltados à coletividade (determinantes externos, finalidades, instrumentos) ou à individualidade (motivos, intenções, capacidades) certamente exerceram influência sobre a atividade de elaborar o MDG e, posteriormente, a SD, pelo grupo de professores que participou da SF. Ficando, portanto, claro que é necessário que tais elementos sejam levados em consideração quando nos voltamos às possibilidades de desenvolvimento dos saberes e capacidades docentes dos professores envolvidos, discussão a ser abordada por nós em nossa tese de doutoramento.

\section{Mediação para o desenvolvimento docente}

As atividades psicológicas, de acordo com Vygotsky (1978), se organizam em dois tipos que se complementam: funções psicológicas inferiores e funções psicológicas superiores, sendo essas últimas as que constituem a preocupação central dos estudos vygotskyanos, por serem funções tipicamente humanas, carregadas de intencionalidades, voluntárias e conscientemente controladas.

As funções psicológicas superiores (tais como: o controle consciente do comportamento, a atenção e memória voluntária, a memorização ativa, o pensamento abstrato, raciocínio dedutivo etc.) emergem sob o efeito de elementos externos geradores de contradições/conflitos com a organização psíquica herdada (as funções psicológicas inferiores). Assim, elementos externos provocam as relações entre as funções psicológicas inferiores e ao mesmo tempo fornecem ao organismo elementos cuja apropriação gera para as funções psicológicas um teor totalmente novo até então (BRONCKART, 2013). Sendo, 
pois, por meio da inter-relação desses dois processos que podem vir a emergir as funções psicológicas superiores.

Deparamo-nos, assim, com um conceito fulcral para o interacionismo social - a mediação: "Mediação, em termos genéricos, é o processo de intervenção de um elemento intermediário numa relação; a relação deixa, então, de ser direta e passa a ser mediada por esse elemento." (OLIVEIRA, 1997, p. 26).

Para Vygotsky, a relação do homem com o mundo se dá sempre mediada, seja por instrumentos, seja por signos. Essa não é, pois, uma relação direta, conforme demonstra a Figura 4:

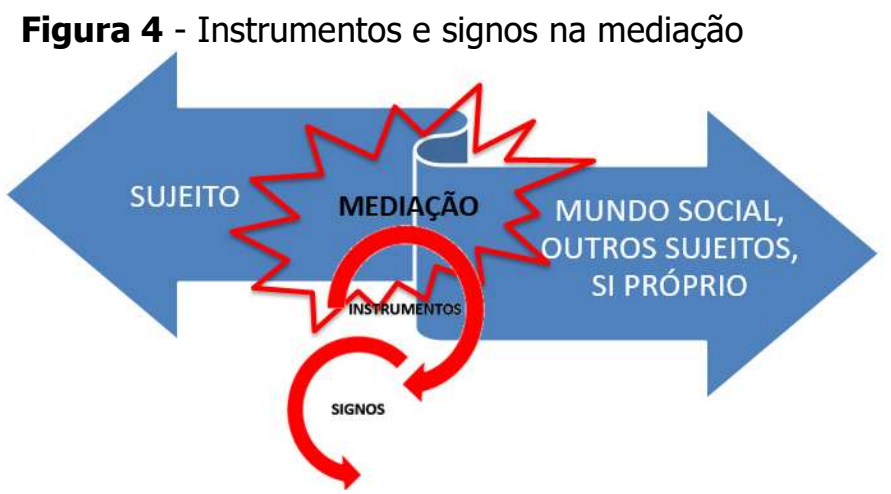

Fonte: a autora.

Assim, em uma perspectiva marxista, o termo instrumento assume no interacionismo social o caráter de um elemento interposto entre o trabalhador e o objeto de seu trabalho, ampliando as possibilidades de transformação da natureza, sendo assim um objeto social e mediador da relação entre o sujeito e o mundo em que está inserido, constituindo-se em elementos externos ao sujeito, voltados para fora dele, com a função de provocar mudanças nos objetos. (OLIVEIRA, 1997).

O signo, também um elemento mediador, "age como um instrumento da atividade psicológica de maneira análoga ao papel de um instrumento no trabalho" (OLIVEIRA, 1997, p. 30). Contudo, o faz no campo psicológico. Também denominados de instrumentos psicológicos, os signos são orientados 
para o próprio indivíduo, para seu interior, dirigindo-se ao controle das ações psicológicas, seja do indivíduo em si ou mesmo de outra pessoa. De acordo com Oliveira (1997, p. 30) "são ferramentas que auxiliam nos processos psicológicos e não nas ações concretas, como os instrumentos".

Partindo do pressuposto de que o que nos torna humanos, diferenciandonos dos demais animais, é justamente a atividade mediada por instrumentos e signos, dentre os quais a linguagem assume papel crucial nesse processo de mediação, faz-se mister a compreensão da função mediadora dos instrumentos e signos:

[...] o uso de mediadores aumentou a capacidade de atenção e de memória e, sobretudo, permitiu maior controle voluntário do sujeito sobre sua atividade. [...] A mediação é um processo essencial para tornar possível atividades psicológicas voluntárias, intencionais, controladas pelo próprio indivíduo. (OLIVEIRA, 1997, p. 33)

Stetsenko (2016) ao apresentar uma expansão da abordagem vygotskyana de aprendizagem e desenvolvimento, a qual é cunhada como "Postura Ativista Transformadora - PAT"5, também trata da noção de mediação, ampliando-a, a partir do conceito de PAT. De acordo com a pesquisadora, a mediação é o ponto chave, indispensável em tudo o que nos constitui enquanto humanos, principalmente, no ensino, na aprendizagem e no desenvolvimento.

Assim, o processo de formação continuada denominado por nós como uma SF apresenta-se permeado por diversos elementos com potencialidades de se constituírem como elementos de mediação cognitiva, dentre eles o MDG/MTG, SD e o próprio gênero de texto. Tais elementos de mediação cognitiva se constituíram como tal a partir de um contexto de formação em que os professores participantes foram envolvidos em processos de um agir concreto - a elaboração de sequências didáticas. A partir dessa proposta, o que se buscou foi que a ação do professor the possibilitasse passar de um status de mero agente para o de um ator, o que envolve a agência do interactante, com vistas ao seu

\footnotetext{
${ }^{5}$ Transformative Activist Stance - TAS
} 
desenvolvimento, o qual não é visto como acumulações de mudanças unitárias e desconectadas. Nas palavras de Vygotsky, desenvolvimento é:

[...] um processo dialético complexo, caracterizado por periodicidade, desigualdade no desenvolvimento de diferentes funções, metamorfoses ou transformações qualitativas de uma forma em outra, entrelaçamento de fatores externos e internos e processos adaptativos. (VYGOTSKY, 1978 , p. 73, tradução nossa) ${ }^{6}$

Vygotsky ainda afirma que aprendizagem e desenvolvimento estão interrelacionados na vida do indivíduo desde que nasce e que a aprendizagem escolar acrescenta nessa interrelação algo fundamentalmente novo, o que nos direciona para a importância do processo de ensino e aprendizagem ao discutirmos o desenvolvimento humano. Nesse sentido, assumimos em nosso trabalho mais dois conceitos essenciais nos estudos vygotskyanos: o nível de desenvolvimento atual e a zona de desenvolvimento proximal:

\begin{abstract}
A zona de desenvolvimento proximal define as funções que ainda não amadureceram, mas estão em processo de maturação, funções que amadurecerão amanhã, mas que estão atualmente em estado embrionário. [...] 0 nível real de desenvolvimento caracteriza 0 desenvolvimento mental retrospectivamente, enquanto a zona de desenvolvimento proximal caracteriza o desenvolvimento mental prospectivamente. (VYGOTSKY, 1978, p. 86, tradução nossa) ${ }^{7}$
\end{abstract}

Ao envolver esses dois conceitos em processos de discussão acerca do desenvolvimento profissional de professores, estamos assumindo que, assim como ocorre com a criança em idade escolar, o profissional em formação continuada também necessita passar por processos de ensino e aprendizagem possibilitadores de novas zonas de desenvolvimento proximal, a fim de despertar

\footnotetext{
6 "[...] a complex dialectical process, characterized by periodicity, unevenness in the development of diferente functions, metamorphosis or qualitative transformations of one form into another, intertwining of external and internal factors, and adaptive processes".

7 "The zone of proximal development defines those functions that have not yet matured but are in the process of maturation, functions that will mature tomorrow but are currently in an embryonic state. [...] The actual developmental level caracterizes mental development retrospectively, while the zone of proximal development caracterizes mental development prospectively."
} 
novos e variados processos internos de desenvolvimento. O que ocorrerá com e a partir de mediações materiais (instrumentos) e semióticas (signos). Assim, seu nível real de desenvolvimento poderá vir a ser desafiado/questionado/(des)estruturado por um novo nível de desenvolvimento proximal. Entendemos que, ainda aí, não poderíamos afirmar ter havido desenvolvimento profissional desse professor, pois de acordo com Vygotsky (1978) quando ocorre a assimilação de um novo conceito, de uma nova operação, os processos de desenvolvimento não estão concluídos, mas sim, apenas iniciando a partir daí.

Complementando essas reflexões, ao tratar da importância da agência para o desenvolvimento do agente, Vianna e Stetsenko (2006, p. 87) também nos remetem a Vygotsky quando asseveram que:

[...] o desenvolvimento de todo e qualquer ser humano, incluindo o desenvolvimento da mente como originado de ações e intrinsecamente conectado a elas, pode ser visto como uma participação, instanciação (execução) e contribuição para as práticas transformadoras colaborativas contínuas das pessoas, isto é, à cultura e à própria sociedade. Consequentemente, pode-se dizer que mente e conhecimento, para Vygotsky, emergem essencialmente de dentro, de fora e através de práticas de transformação colaborativa e representam apenas uma forma (ou modo) na qual essas práticas existem (embora não explicitamente).

É nesse sentido que entendemos a SF como propiciadora de possíveis configurações de agência por parte dos professores participantes, uma vez que a proposta de uma SF é justamente que o professor não seja somente um expectador (um agente), mas para além disso, que se envolva em práticas colaborativas contínuas de agência (um ator) entre os participantes de modo a contribuir com a criação de práticas transformadoras colaborativas contínuas entre os profissionais de um modo mais amplo.

Isso posto, passamos, a seguir, para algumas considerações acerca do percurso metodológico deste estudo.

\section{Percurso Metodológico}


O presente artigo representa um recorte do estudo de doutorado desenvolvido por nós, o qual envolveu uma SF iniciada no ano de 2017 e concluída em 2018. Contou com a participação de 07 professores, dos quais 02 participaram de todo o processo da $\mathrm{SF}$, a saber: participação no curso, implementação da SD, sessões de autoconfrontação simples e cruzada, extensão ao coletivo.

As análises aqui apresentadas recaíram sobre o processo de transposição didática externa do gênero infográfico, mais especificamente sobre seu MTG bem como sobre a SD elaborada por uma professora durante sua participação na SF. Importa destacar que a referida SD foi escolhida para compor este estudo por ter sido a única a ser implementada em sala de aula por dois dos professores participantes da SF.

Apresentamos, no Quadro 2, as perguntas de pesquisa voltadas à análise da SD em estudo:

Quadro 2 - Perguntas, objetivos, conjunto de dados e procedimentos de análise

\begin{tabular}{|c|c|c|c|}
\hline Pergunta & Objetivo & $\begin{array}{l}\text { Conjunto de } \\
\text { dados }\end{array}$ & $\begin{array}{l}\text { Procedimentos } \\
\text { de análises }\end{array}$ \\
\hline $\begin{array}{l}\text { Q u a i s s ã o a s } \\
\text { dimensões ensináveis } \\
\text { do gênero infográfico, } \\
\text { identificáveis a partir } \\
\text { do MTG? }\end{array}$ & $\begin{array}{l}\text { A p resentar as } \\
\text { dimensões ensináveis } \\
\text { do gênero infográfico. }\end{array}$ & $\begin{array}{l}\text {-Corpus composto } \\
\text { por } 10 \text { textos do } \\
\text { gênero infográfico. } \\
\text {-Corpus composto por } \\
05 \text { estudos de } \\
\text { especialistas sobre o } \\
\text { gênero. }\end{array}$ & $\begin{array}{l}\text {-Dispositivo orientador } \\
\text { para modalização do } \\
\text { gênero. }\end{array}$ \\
\hline $\begin{array}{l}\text { Quais dimensões } \\
\text { ens in áve is d o } \\
\text { gênero infográfico } \\
\text { estão presentes na } \\
\text { SD elaborada por uma } \\
\text { professora durante } \\
\text { sua participação em } \\
\text { uma SF? }\end{array}$ & $\begin{array}{l}\text { I d e n ti fi c a r a s } \\
\text { aproximações e/ou os } \\
\text { distanciamentos entre } \\
\text { os e l e m e n t o s } \\
\text { ensináveis do gênero } \\
\text { infográfico e duas } \\
\text { ve rs õ es d a S D } \\
\text { (a primeira a última) } \\
\text { elaboradas pela } \\
\text { referida professora. }\end{array}$ & $\begin{array}{l}\text { A 1a e a última versão } \\
\text { da SD elaborada pela } \\
\text { professora foco deste } \\
\text { estudo. }\end{array}$ & $\begin{array}{l}\text {-Macroestrutura da } \\
\text { SD, em suas } 2 \text { versões. } \\
\text {-Dimensões ensináveis } \\
\text { do gênero infográfico. }\end{array}$ \\
\hline
\end{tabular}

Fonte: a autora.

Feitas essas explicitações acerca dos encaminhamentos metodológicos, passamos às análises. 


\section{Algumas Análises}

\section{Estudo do gênero infográfico em teses e dissertações}

No caso específico da SD utilizada neste estudo, a escolha pelo gênero infográfico justifica-se pelo fato de ser um gênero marcadamente multimodal, característica que tem estado cada vez mais presente nos contextos de leitura e escrita, exigindo, portanto, um cidadão com capacidades de compreensão leitora e expressão escrita cada vez mais afinadas com as Capacidades Multissemióticas, seja em uma língua adicional ou língua materna. Exemplo disso é a variedade de textos do gênero infográfico que têm inundado jornais e revistas impressos bem como em ambientes virtuais. Apenas para exemplificar, a revista SuperInteressante, edição 382 de novembro de 2017, foi editada somente com infográficos, um total de 24.

Ao fazermos uma busca, no portal de Teses e Dissertações do Portal da Capes, por pesquisas que tratavam do ensino desse gênero, lançamos mão de alguns grupos de palavras-chave, empregadas entre aspas, a saber: 1) "gênero textual - infográfico - língua inglesa" e 2) "infográfico - língua inglesa" e não tivemos nenhuma pesquisa encontrada; 3) "gênero textual - infográfico" e encontramos três pesquisas. Fizemos ainda outra tentativa utilizando somente a palavra-chave 4) "infográfico" e, sem aplicar nenhum refinamento para a pesquisa, obtivemos um total de 115 resultados. Aplicamos, então, a mesma palavra-chave 5) "infográfico", contudo aplicando o refinamento relacionado às grandes áreas do conhecimento, para a qual selecionamos as áreas de: linguística, letras e artes. A partir dessa última busca obtivemos um total de 19 pesquisas.

Fizemos a leitura do resumo dessas 19 pesquisas, assim como das 03 pesquisas encontradas em nossa terceira busca, e, com base na leitura dos resumos, destacamos 05 pesquisas, as quais pareceram poder nos subsidiar em nosso estudo. As demais tratavam do ensino de língua materna/do ensino de 
Arte, ou ainda focavam somente nos processos de leitura de infográficos, além do estudo de infográficos em meio digital, ou de algum aspecto específico deste gênero, tal como o uso das cores.

Das 05 pesquisas selecionadas, apenas 01 (ASSUNÇÃO, 2014) tratava do ensino do gênero infográfico em aula de língua inglesa. Assunção (2014) desenvolveu seu estudo de mestrado, tendo como foco o contexto de ensino superior e apresentou como objetivo analisar as estratégias e o processo de construção de sentido em leituras de infográficos. Empregou como referencial teórico a semiótica social e a gramática do design visual.

Em um sentido inverso, porém, ao seguido pelas pesquisas, observamos que há um aumento da presença de textos do gênero infográfico não só em livros didáticos aprovados nas últimas edições do PNLD, mas na sociedade como um todo. Isso nos faz refletir sobre o quanto os professores estão ou não preparados para abordar esse gênero nas aulas de ensino fundamental II e ensino médio, revelando a necessidade de pesquisas voltadas a essa temática. Ao mesmo, os resultados dessa busca justificam e ratificam a necessidade do estudo apresentado por nós, o qual aborda o gênero infográfico no contexto de ensino e aprendizagem de línguas adicionais (língua inglesa) na educação básica.

\section{O que dizem os especialistas acerca do gênero infográfico}

Conforme já expusemos anteriormente, não encontramos, em nossas buscas, uma diversidade de trabalhos de pesquisa que enfocassem o processo de ensino e aprendizagem de infográficos em aulas de língua inglesa. Apenas um (01) trabalho foi encontrado. Contudo, nem mesmo esse trabalho foi utilizado por nós por pautar-se em um referencial teórico não condizente com o que adotamos, além de enfocar o contexto de ensino de leitura no Ensino Superior ou seja, contexto também não condizente com o de nossa pesquisa.

Sendo assim, trouxemos como referência de especialistas que já trataram do estudo do gênero infográfico, os seguintes estudos: Dionísio (2013), Kanno 
(2013), Teixeira (2010), Al Hosni (2016), Gonçalves e Rosolem (2018). Destacamos que esses trabalhos não foram encontrados no Portal de Teses e Dissertações da CAPES, mas sim em buscas realizadas por nós no Google acadêmico, no primeiro semestre de 2018.

Dionísio organizou o livro virtual "Série Verbetes Enciclopédicos Diversidade de Linguagem no Ensino Médio - Gráfico e Infográfico". A produção do material contou com a participação de acadêmicos pibidianos da Universidade Federal de Pernambuco - UFPE. De acordo com Dionísio, a motivação para elaboração do material adveio de situações vivenciadas pelos futuros professores, durante atuação em escolas públicas de Recife, os quais se depararam com alunos que ainda nem sequer conheciam as denominações de certos gêneros, como por exemplo, charge. Diante da situação, o grupo liderado por Dionísio, propôs-se a escolher gêneros multissemióticos para realizarem um estudo mais aprofundado de modo a culminar com a coletânea Série Verbetes. Dentre os gêneros escolhidos, estão os infográficos.

Teixeira (2010) - uma pesquisadora sobre infográficos desde o ano de 2004 - produziu o livro "Infografia e jornalismo - conceitos, análises e perspectivas". A obra apresenta um pouco da história do infográfico, além de abordar questões relacionadas ao ensino de infográfico, especificamente, em cursos de jornalismo. No início de seu livro, a autora menciona, de forma bem acessível e simples sua visão do que seja infografia: "[...] a integração entre texto e imagem usada para explicar uma série de coisas que existem no nosso planeta e no universo. "(TEIXEIRA, 2010, p. 9), devendo-se ter o cuidado em sua elaboração de modo que nem a imagem, nem o texto se sobressaiam a ponto de um ou outro se tornar indispensável. Indica também quais os elementos característicos desse gênero, os quais ela classifica como icônicos e tipográficos: fotografias, ilustrações, gráficos, dentre outros. Quanto à organização de textos desse gênero, a pesquisadora afirma haver elementos obrigatórios, a saber: título, texto introdutório, indicação das fontes, assinatura dos autores. Quanto à classificação, Teixeira apresenta dois grandes grupos: os enciclopédicos e os 
jornalísticos, os quais ainda podem ser subdivididos em independentes ou complementares. De acordo com a autora:

[...] enciclopédicos estão aqueles centrados em explicações de caráter mais universal como, por exemplo, detalhes do funcionamento do corpo humano; como se formam as nuvens; o que são bactérias; o que é ciranda financeira; o que são partidos políticos; quais são os controles e comandos da cabine de um avião, entre outros. [...] costuma ser bastante generalista. Enquanto os infográficos enciclopédicos produzem abordagens mais genéricas de diferentes fenômenos, os jornalísticos se atêm a aspectos mais próximos da singularidade dos fatos, ideias ou situações narrados. (TEIXEIRA, 2010, p. 42,47 , grifo do original).

Tendo a clareza da diferenciação entre enciclopédico e jornalístico, a Figura 6 intenciona distinguir os independentes dos complementares:

Figura 6 - Classificação dos infográficos

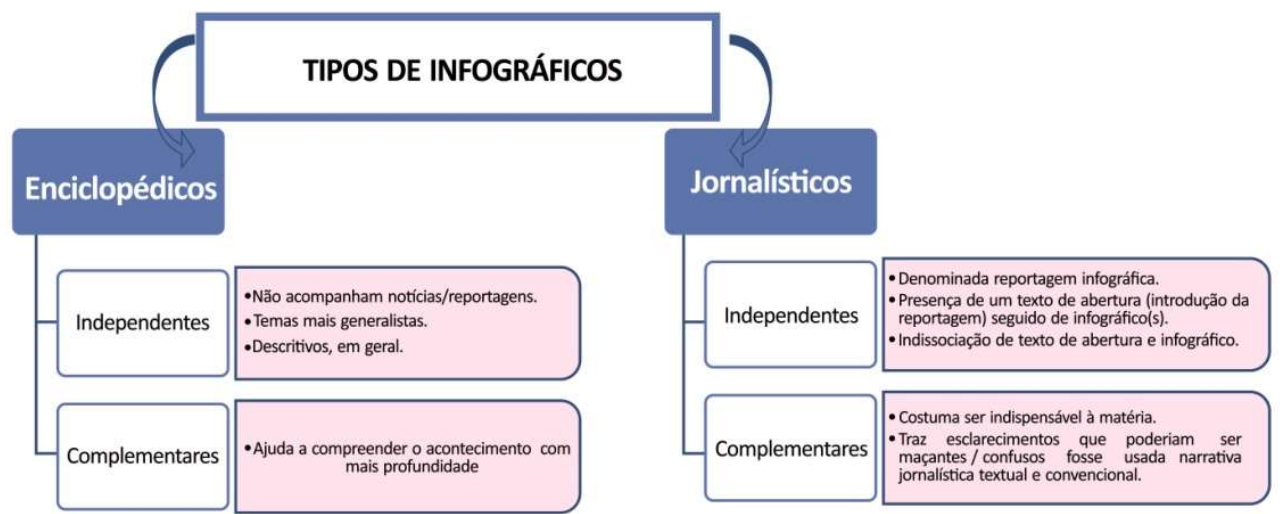

Fonte: a autora, com base em Teixeira (2010).

A categorização de infográfico apresentada por Teixeira - enciclopédico independente, enciclopédico complementar, jornalístico independente, jornalístico complementar pode ainda ser complementada pelas categorias apresentadas por Kanno (2013) em seu livro "Infografe - Como e por que usar infográficos para criar visualizações e comunicar de forma imediata e eficiente". Uma publicação altamente valiosa para aqueles que são da área do jornalismo, 
mas também útil e esclarecedora para toda e qualquer pessoa que queira conhecer mais sobre esse gênero de texto.

De acordo com o autor

O infográfico não tem o poder milagroso de "fazer coisas complexas ficarem simples", ele é apenas a melhor maneira de representar certo tipo de informação. Da mesma forma que o texto é o meio mais eficaz de descrever outros tipos de informação e a foto é mais eficiente em outros casos. (KANNO, 2013, p. 11)

Enquanto Teixeira categoriza os infográficos a partir dos objetivos a que se propõem, as categorias tratadas em Kanno referem-se mais às formas de organização dos infográficos, pois, segundo o autor, faz-se necessário conhecer os modelos mais comuns de infografias tendo em vista uma escolha adequada em relação ao conteúdo/forma. Para tanto, ele apresenta quatro grandes categorias de agrupamentos dos infográficos: artes-texto, gráficos, mapas, ilustrados. Categorias essas ainda com possibilidades de subdivisões, conforme demonstrado no Quadro 3: 


\section{Quadro 3 - Categorização dos infográficos}

\begin{tabular}{|c|c|c|}
\hline Categorias & $\begin{array}{l}\text { Subdivisões } \\
\text { das categorias }\end{array}$ & Especificidades de cada categoria \\
\hline \multirow{14}{*}{ ARTES / TEXTO } & Cronologia & Mostra datas mais importantes. \\
\hline & Dicas & Reúne instruções ao leitor. \\
\hline & Score & Um número é a principal informação. \\
\hline & Fac-símile & $\begin{array}{l}\text { Reprodução de um ou mais documentos } \\
\text { relevantes para a matéria. }\end{array}$ \\
\hline & Ficha & $\begin{array}{l}\text { Concentra principais características do } \\
\text { personagem (pais, empresa, pessoa etc.). }\end{array}$ \\
\hline & Frases & Opiniões sobre o assunto. \\
\hline & Glossário & $\begin{array}{l}\text { Traz significados de termos difíceis, mas } \\
\text { imprescindíveis à reportagem. }\end{array}$ \\
\hline & Lista/Ranking & Informações em tópicos. \\
\hline & $\begin{array}{c}\text { Para } \\
\text { entender/resumo }\end{array}$ & Apresenta "quem, quando, onde, por quê". \\
\hline & $\begin{array}{l}\text { Perguntas e } \\
\text { respostas }\end{array}$ & Estilo de entrevista. \\
\hline & Próximos passos & Indica como o assunto deve se desenvolver. \\
\hline & Sobe-desce & Associar valor: ganhou/perdeu/ficou igual. \\
\hline & Tabela & Textos ou números em colunas. \\
\hline & Testes & Forma interativa de transmitir informações. \\
\hline \multirow{4}{*}{ GRÁFICOS } & De Linha & Evolução de uma ou mais variáveis no tempo. \\
\hline & De barras & Compara valores, mostra evolução. \\
\hline & Pizza/queijo & $\begin{array}{l}\text { Mostra como uma quantidade geral se divide em } \\
\text { diferentes categorias. }\end{array}$ \\
\hline & Area & $\begin{array}{l}\text { Compara valores de uma ou mais categorias } \\
\text { usando imagens proporcionais. }\end{array}$ \\
\hline \multirow{3}{*}{ MAPAS } & De localização & Localiza geograficamente o assunto, \\
\hline & De ação & Explica mudanças ou movimentos geográficos. \\
\hline & Estatístico & $\begin{array}{l}\text { Usa cores, sinais gráficos para mostrar dispersão } \\
\text { geográfica dos dados. }\end{array}$ \\
\hline \multirow{6}{*}{ ILUSTRADOS } & Arte-foto & $\begin{array}{l}\text { Uma ou mais fotos manipulada para evidenciar } \\
\text { informação. }\end{array}$ \\
\hline & $\begin{array}{c}\text { Corte } \\
\text { esquemático }\end{array}$ & Mostra como o personagem é por dentro. \\
\hline & $\begin{array}{l}\text { Fluxograma / } \\
\text { passo a passo }\end{array}$ & Representação de acontecimentos ou processos. \\
\hline & Organograma & $\begin{array}{l}\text { Define grafícamente posições hierárquicas ou de } \\
\text { relacionamentos. }\end{array}$ \\
\hline & Storyboard & Uso de quadrinhos para relato. \\
\hline & $\begin{array}{c}\text { Página } \\
\text { infográfica }\end{array}$ & $\begin{array}{l}\text { Combina tipos de infografia para traduzir } \\
\text { visualmente a reportagem. }\end{array}$ \\
\hline
\end{tabular}

Fonte: a autora, com base em Kanno (2013).

Além de apresentar as diferentes categorias, Kanno ainda dá dicas em seu livro sobre quando usar uma ou outra categoria, destacando que o fator definidor dessa escolha não será o tema, mas sim o enfoque, a abordagem que se deseja dar a esse tema. 
A outra referência trazida por nós concentra-se em um contexto de ensino de inglês como língua adicional. $O$ artigo "O poder da imagem no ensino de língua inglesa ${ }^{81}$, de Al Hosni (2016), apresenta-se diretamente ligado ao contexto de nosso estudo no que se refere ao ensino de língua inglesa como língua adicional, ainda que o autor trate desse ensino na Educação Superior. As considerações trazidas por ele corroboram nossas afirmações de que o estudo do gênero infográfico faz-se necessário devido à necessidade de atendermos a essa nova geração de pessoas muito mais visuais e tecnológicas. $O$ autor apresenta dados ratificando tal afirmação, dentre os quais, $65 \%$ da população mundial são aprendizes visuais e, ainda, 70\% dos receptores de informações em nosso corpo estão em nossos olhos. Ou seja, um número considerável de nossos alunos poderá ter a capacidade de receber melhor as informações visuais. Para tanto, faz-se necessário um ensino para que essa capacidade multissemiótica de nossos alunos seja melhor desenvolvida.

O artigo de Gonçalves e Rosolem (2018), muito embora voltado para o ensino de língua materna, pauta-se pelo mesmo referencial teórico assumido por nós, inclusive, propondo um MDG para o trabalho com infográfico em sala de aula. Diante disso, consideramos um referencial importante para nosso estudo. As autoras Gonçalves e Rosolem (2018), apresentam o infográfico como um gênero a partir das categorias "conteúdo temático, estilo e construção composicional" propostas por Voloshinov (1997). Quanto ao conteúdo temático, o gênero em questão trata de informações científicas, teóricas, históricas e estatísticas. Com relação ao estilo, o autor possui liberdade de criação quanto à estrutura, mas sempre se vinculando a um tema pré-estabelecido. E, finalmente, no que tange à construção composicional, as autoras mencionam a presença de imagens, quadros, esquemas, textos verbais e não-verbais. Além dessa categorização que ajuda a definir o infográfico como um gênero, as pesquisadoras apresentam também o que elas denominam como uma modelização resumida do gênero infográfico.

\footnotetext{
${ }^{8}$ The power of image in English language teaching.
} 


\section{As dimensões ensináveis do gênero infográfico}

Pautamo-nos, portanto, no quadro de referências já mencionado, assim como em uma amostra de 10 textos $^{9}$ do gênero em estudo para apresentar o que denominamos de MTG. Contudo, para este artigo, devido ao limite de espaço, focamos apenas em um quadro-resumo contendo dimensões ensináveis desse gênero, a partir dos elementos presentes no Dispositivo Orientador para Modelização do Gênero, já discutido anteriormente.

Segue o Quadro 4, com os possíveis elementos ensináveis em um processo de ensino e aprendizagem pautado pelo gênero infográfico.

Quadro 4 - Dimensões ensináveis do gênero infográfico

\section{Características discursivas}

Discurso teórico, mundo do expor autônomo ao tratar de infográficos da categoria enciclopédico. Sendo da categoria jornalístico pode se encaixar no discurso da ordem do narrar, mundo do narrar acontecimento vivido (relato).

Alguns elementos são obrigatórios: título, texto introdutório (poucas linhas com informações gerais - uma espécie de lead), Indicação das fontes, assinatura dos autores.

$>\mathrm{O}$ título pode vir combinado com uma imagem metafórica.

$>0$ tamanho / a extensão do texto também não é rígido. Há infográficos de uma página inteira (de jornal ou revista), outros com duas ou mais páginas.

$>$ A forma de organização dos conteúdos é bem livre e diversificada

$>$ Tanto as imagens, quanto os textos verbais devem ser organizados de modo que a leitura se dê da esquerda para a direita.

$>\mathrm{A}$ informação principal deve estar em destaque no texto, de modo a se sobressair diante das demais.

$>0$ texto pode-se planificar em sequências descritiva, explicativa, narrativa, injuntiva, a depender dos objetivos a que se propõem o infográfico.

Presença de frases e palavras curtas.

Possibilidades de divisões no texto por meio de subtítulos/intertítulos.

9 Seguem os títulos dos 10 textos selecionados para nossa análise: 1) The importance of technology in education. 2) Then vs Now - How teaching in schools has changed over time. 3) Education by numbers. 4) Wireless technology in the classroom. 5) Innovation in Education Public opinion poll of students, teachers and parentes. 6) Social media in the classroom. 7) Technology enhances learning. 8) Technology use 11/12 yr old boys. 9) Teaching and technology. 10) What infographics are. Desses 10 textos, os cinco primeiros foram utilizados pela professora Carla para elaborar a sua SD. 


\section{Características contextuais
(contexto imediato e contexto social mais amplo)}

> Prática social pertencente originalmente à esfera jornalística, pode também estar presente em outras esferas de circulação social, a saber: literária, científica, escolar, produção e consumo.

> Gênero multimodal, escrito.

> Circula em vários suportes: jornais, livros, revistas, tanto impressos quanto online.

> Complementa notícias/reportagens, mas também pode ser um texto independente.

> O conteúdo temático pode ser muito diversificado, como por exemplo, informações científicas, teóricas, históricas, narrativas, dados estatísticos.

- A pessoa física que produz infográficos (emissor), em sua origem, são profissionais da esfera jornalística. Atualmente também profissionais específicos - os infografistas. Ainda pode ser produzido por uma diversidade de produtores que têm a intenção de comunicar alguma informação científica, teórica, história, narrativa, estatística.

> O destinatário, assim como o emissor, é bem diversificado, podendo ser de várias faixas-etárias, a depender dos interesses temáticos.

> O papel discursivo estabelecido entre enunciador e destinatário é marcado por uma relação de divulgação de informação por parte do enunciador e de consumo dessa informação por parte do destinatário, o qual pode vir a agir socialmente com base nessas informações.

> O gênero tem assumido, cada vez mais, grande importância em uma sociedade também cada vez mais marcada pela presença de elementos multissemióticos.

> Textos desse gênero são marcados por um tom de objetividade.

> Devido à diversidade do conteúdo temático, os mapas semânticos também apresentam essa diversidade.

- As possíveis práticas praxiológicas podem surgir do interesse em divulgar uma informação de interesse de um grupo específico ou mais geral, de uma forma mais direta e visualmente mais acessível.

> O gênero tem suas origens desde as pinturas pré-históricas, sendo essas consideradas as primeiras manifestações da infografia.

- Levando em conta o contexto social mais amplo em que esse gênero pode vir a circular, há uma estreita relação com uma sociedade marcadamente visual e imediatista, em que as informações e as notícias surgem e desaparecem em questões de horas, minutos.

> Os textos podem conter vozes de especialistas nos temas enfocados, vozes de historiadores, de agências oficiais de pesquisa, de jornalista, de pesquisadores com interesse em divulgar seus temas de pesquisa. Enfim, as vozes assim como a temática, pode ser muito diversificada. Contudo, são marcadas pelo interesse em divulgar dados, informações - sendo, portanto representativas de fontes científicas, de argumentos de autoridades, de dados estatísticos, de elementos narrativos.

\section{Características linguístico-discursivas}

$>$ A escolha do léxico está relacionada ao assunto do infográfico.

$>$ Linguagem mais informal, coloquial, mas sempre respeitando a norma culta.

$>$ Presença de substantivos, adjetivos, advérbios, palavras interrogativas, de grupos nominais.

$>$ Tempo presente simples dos verbos, modo imperativo, voz passiva.

$>$ Grau comparativo e superlativo dos adjetivos.

$>$ Abreviações.

$>$ Frases exclamativas, interrogativas, declarativas.

$>$ Presença de números, porcentagem.

\section{Características multissemióticas}

$>$ Presença de elementos visuais (imagens, fotos, cores, tipografia diferenciada, gráficos, mapas, fluxogramas, organogramas, tabelas - combinados ou não) mas sempre aliados à informação verbal presente no texto de modo que uma seja suporte para melhor entendimento da outra. Binômio imagem/texto com função não apenas expositiva, mas explicativa.

$>$ Deve-se ter o cuidado de manter a relação indissociável entre imagem e texto. A imagem não pode ser uma mera ilustração.

$>$ Linhas e setas podem ser inseridas para indicar as direções de leituras.

As cores devem estar em harmonia com as imagens e o texto verbal.

$>$ Uso de tipografia diferenciada com objetivos específicos.

Fonte: a autora. 
Apresentadas as dimensões ensináveis do gênero infográfico, passamos à apresentação da macroestrutura de duas versões da SD, cujo enfoque foi o gênero infográfico, produzida por uma professora durante sua participação em uma SF. Apresentamos a primeira e a última versão da referida SD, estabelecendo paralelos entre suas atividades e os elementos ensináveis do gênero.

\section{O Gênero Infográfico na Sequência Didática de Carla}

Durante o curso realizado no ano de 2017, uma das professoras participantes (professora Carla) escolheu trabalhar com o gênero infográfico como objeto de ensino da SD que produziria. O trabalho de elaboração do referido material aconteceu nos encontros presenciais, bem como em outros momentos além dos horários estipulados para o curso. Os professores contaram com a mediação da professora formadora, não só presencialmente, como também em troca de e-mails. Contudo, todo esse processo de mediação não será aqui abordado devido ao objetivo estabelecido para este artigo.

Após transcorridos 04 encontros de 4 horas (um total de 16 horas), os professores participantes deram início ao processo de elaboração de suas SD. Processo esse que se estendeu aos 04 encontros restantes, totalizando também 16 horas, além dos trabalhos realizados em outros momentos.

A SD de Carla, intitulada Technology in my life $x$ technology in my school tinha como objetivo o ensino do gênero infográfico aliado a discussões acerca do tema tecnologia no contexto educacional e na vida particular dos alunos.

Em sua primeira versão, a SD se organiza em cinco páginas, divididas em quatro seções: Introdução, Módulo 1, Módulo 2, Módulo 3 e apresentou três textos do gênero infográfico. A versão final, com dez páginas, apresenta dez seções: Página inicial, Módulo 1, Produção inicial - parte 1, Produção inicial parte 2, Módulo 2, Produção inicial - parte 3, Módulo 3, Revisão e reescrita, 
Módulo 4, Produção final e compartilhamento. Contou com cinco (05) textos do gênero.

Segue, no Quadro 5, a descrição da primeira versão da SD, bem como a correspondência entre suas partes e a estrutura de base de uma SD. Além disso, também mencionamos quais elementos ensináveis do gênero foram contemplados nas atividades propostas.

Quadro 5 - Primeira versão da SD de Carla

\begin{tabular}{|c|c|c|}
\hline $\begin{array}{l}\text { ESTRUTURA DE } \\
\text { BASE DE UMA SD }\end{array}$ & $\begin{array}{c}\text { DESCRIÇÃO DA 1a VERSÃO DA SD } \\
\text { DE CARLA }\end{array}$ & $\begin{array}{l}\text { RELACCÃO COM ELEMENTOS } \\
\text { ENSINÁVEIS DO GÊNERO } \\
\text { INFOGRAFICO }\end{array}$ \\
\hline $\begin{array}{l}\text { Página Inicial } \\
\text { (apresentação da } \\
\text { s i t u a ç ão d e } \\
\text { comunicação, dos } \\
\text { objetivos, destaque } \\
\text { ao gênero em } \\
\text { estudo) }\end{array}$ & $\begin{array}{l}\text { Não há uma página inicial com } \\
\text { destaque para essas informações, em } \\
\text { uma mesma página estão as } \\
\text { informações iniciais e o Módulo 1. } \\
\text { Os objetivos são elencados, } \\
\text { juntamente com eles, a situação de } \\
\text { comunicação. } \\
\text { Não há destaque para o gênero, mas } \\
\text { sim para o tema, por meio de uma } \\
\text { imagem. } \\
\text { O título já foi dado, mas com } \\
\text { enfoque no tema. } \\
\text { O gênero é mencionado no parágrafo } \\
\text { introdutório, bem como o uso de } \\
\text { imagens. }\end{array}$ & $\begin{array}{l}\text { Não há explicitação de } \\
\text { elementos ensináveis. } \\
\text { Apenas o tema se destaca } \\
\text { por meio de imagens. } \\
\text { O gênero é apenas } \\
\text { mencionado no parágrafo } \\
\text { introdutório. }\end{array}$ \\
\hline Módulo 1 & $\begin{array}{l}\text { Módulo } \mathbf{1}-\text { denominado de } \\
\text { Contextualizing. } \\
\text { Atividade } 1 \text { - apresenta dois vídeos } \\
\text { que tratam do tema. } \\
\text { Atividades } 2 \text { a } 5 \text { - compreensão dos } \\
\text { vídeos - foco no tema. } \\
\text { Atividade } 6 \text { - frequência de uso da } \\
\text { tecnologia. } \\
\text { Homework - Pesquisa por infográficos } \\
\text { relacionados ao tema tecnologia. }\end{array}$ & $\begin{array}{l}\text { - Tema } \\
\text { - Léxico } \\
\text { - Advérbios de frequência }\end{array}$ \\
\hline Produção Inicial & Não aparece nesta versão. & $x \times 0 x x$ \\
\hline Módulo 2 & $\begin{array}{l}\text { Módulo 2: Initial production } \\
\text { Traz um comando para que os alunos } \\
\text { apresentem o resultado de suas } \\
\text { pesquisas. Na mesma atividade } \\
\text { propõe questões para que os alunos } \\
\text { reflitam sobre as características do } \\
\text { gênero. } \\
\text { Traz o infográfico Education by the } \\
\text { numbers. Propões atividade sobre o } \\
\text { layout do gênero, bem como sobre o } \\
\text { tema. } \\
\text { Atividade com enfoque nos numerais. } \\
\text { Atividades sobre a compreensão do } \\
\text { texto apresentado. }\end{array}$ & $\begin{array}{l}\text { - Presença de imagens com } \\
\text { informações. } \\
\text { - Texto curto e objetivo. } \\
\text { - Relação entre os números, } \\
\text { as ilustrações e o texto } \\
\text { verbal. } \\
\text { - Organização do texto - } \\
\text { layout. } \\
\text { Organização em tópicos, } \\
\text { subbtópicos. } \\
\text { - Presença de mapas, } \\
\text { porcentagens, gráficos. }\end{array}$ \\
\hline
\end{tabular}




\begin{tabular}{|c|c|c|}
\hline Produção escrita & Não consta nesta versão. & $x<0<x$ \\
\hline Módulo 3 & $\begin{array}{l}\text { Módulo 3: denominado de } \\
\text { Present Simple - Review } \\
\text { Traz o infográfico Innovation in } \\
\text { Education } \\
\text { Atividade } 1 \\
\text { Enfoca o léxico e uso dos números } \\
\text { Traz o infográfico Technology in } \\
\text { Education } \\
\text { Atividade } 2 \\
\text { Compreensão do texto } \\
\text { Atividade } 3 \text { a } 6 \\
\text { Enfoque em pronomes pessoais e } \\
\text { verbos no tempo presente }\end{array}$ & $\begin{array}{l}\text { - Tempo presente simples } \\
\text { - Tema } \\
\text { - Números }\end{array}$ \\
\hline Revisão e reescrita & Não consta nesta versão. & $x x x x x$ \\
\hline Outros módulos & Não consta nesta versão. & $x<x<x$ \\
\hline Produção final & Não consta nesta versão. & $x x x x x$ \\
\hline
\end{tabular}

Fonte: a autora.

Ao compararmos a primeira versão da SD de Carla com a estrutura de base de uma SD, na qual constam Apresentação da Situação, Primeira Produção, Módulos, Produção Final, observamos que a professora em formação procura atender a essa estrutura, ainda que não a apresente de uma forma completa. A despeito disso, em uma análise mais minuciosa, percebemos que há fragilidades no que tange a atividades voltadas para o desenvolvimento das CL dos alunos, bem como com relação às especificidades de uma SD, a saber: I) os princípios teóricos subjacentes ao procedimento; II) o seu caráter modular; III) as diferenças entre um trabalho com foco em gêneros orais ou escritos; IV) a articulação entre o trabalho na sequência e outros domínios de ensino de língua (DOLZ; NOVERRAZ; SCHNEUWLY, 2010, p. 91). Contudo, essa análise mais minuciosa não será apresentada neste artigo.

Retomando, portanto, o objetivo apresentado ao propormos a análise da $S D$, temos que o foco se constitui em traçar um paralelo entre as atividades tal como estão postas nas duas versões da SD e os elementos ensináveis do gênero infográfico apresentados no MTG.

Nesse sentido, a análise da primeira versão da SD nos mostra a ausência de significativos elementos ensináveis do gênero infográfico, principalmente, no 
que se refere às características contextuais (mais voltadas às Capacidades de Ação e de Significação) e às características discursivas (voltadas às Capacidades Discursivas). Aparecem, respectivamente, 01 elemento (alusão ao tema) e 02 elementos (texto curto e objetivo, layout) nesta versão da SD.

Os elementos pertinentes às características multissemióticas (relacionados às Capacidades Multissemióticas) são um pouco mais contemplados, tendo sido identificados: imagem associada à informação, presença de mapas, porcentagem, gráficos, relação entre texto verbal e não verbal.

Finalmente, os elementos que são mais contemplados em atividades na primeira versão da SD estão ligados às características linguístico-discursivas (voltadas às Capacidades Linguístico-discursivas). Quatro foram os elementos identificados: léxico, advérbios, tempo presente simples dos verbos, numerais.

A seguir, apresentamos, no Quadro 6, a segunda versão da SD elaborada por Carla.

Quadro 6 - Versão final da SD de Carla

\begin{tabular}{|c|c|c|}
\hline $\begin{array}{l}\text { ESTRUTURA DE } \\
\text { BASE DE UMA SD }\end{array}$ & $\begin{array}{l}\text { DESCRIÇÃO DA VERSÃO FINAL DA } \\
\text { SD DE CARLA }\end{array}$ & $\begin{array}{c}\text { RELAÇÃO COM ELEMENTOS } \\
\text { ENSINÁVEIS DO GÊNERO } \\
\text { INFOGRÁFICO }\end{array}$ \\
\hline $\begin{array}{l}\text { Página Inicial } \\
\text { (apresentação da } \\
\text { s i t u a çã o de } \\
\text { comunicação, dos } \\
\text { objetivos, destaque } \\
\text { ao gênero em } \\
\text { estudo) }\end{array}$ & $\begin{array}{l}\text { Há uma página inicial com a } \\
\text { presença de um texto do gênero em } \\
\text { estudo. } \\
\text { Os objetivos continuam os mesmos } \\
\text { da 1a versão. } \\
\text { A situação de comunicação continua } \\
\text { vinculada aos objettivos, mas sem um } \\
\text { destaque à sua importância no estudo } \\
\text { que se inicia. } \\
\text { O título continua o mesmo. } \\
\text { O parágrafo introdutório menciona a } \\
\text { presença de um texto do gênero e } \\
\text { pede que os alunos o observem. }\end{array}$ & $\begin{array}{l}\text { No parágrafo introdutório: } \\
\text { menção ao gênero que } \\
\text { mistura i magens e } \\
\text { i n f o r m a ç õ e s. } \\
\text { O infográfico é apresentado } \\
\text { aos alunos mediante o texto } \\
T \text { h e } n \quad x \quad N \text { o w. }\end{array}$ \\
\hline Módulo 1 & $\begin{array}{l}\text { Módulo } 1 \text { - denominado de } \\
\text { Contextualizing. } \\
\text { Atividade } 1 \text { - apresenta dois vídeos } \\
\text { que tratam do tema. } \\
\text { Atividade } 2 \text { - compreensão dos } \\
\text { vídeos - foco no tema. } \\
\text { Atividade } 3 \text { - frequência de uso da } \\
\text { tecnologia. }\end{array}$ & $\begin{array}{l}\text { - Tema } \\
\text { - Léxico } \\
\text { - Advérbios de frequência }\end{array}$ \\
\hline
\end{tabular}




\begin{tabular}{|c|c|c|}
\hline Produção Inicial & $\begin{array}{l}\text { Produção Inicial } \\
\text { Denominado de } \\
\text { Initial production - part } 1 \\
\text { Homework } \\
\text { Pesquisa por infográficos relacionados } \\
\text { ao tema tecnologia. } \\
\text { Initial production - part } 2 \\
\text { Traz um comando para que os alunos } \\
\text { apresentem o resultado de suas } \\
\text { pesquisas. }\end{array}$ & $\begin{array}{l}\text { - Presença de imagens com } \\
\text { informações. } \\
\text { - Organização do texto - } \\
\text { layout. } \\
\text { - Tema }\end{array}$ \\
\hline Módulo 2 & $\begin{array}{l}\text { Módulo } 2 \text { - denominado de } \\
\text { Thinking about the genre } \\
\text { Atividade } 1 \\
\text { - Questões para que os alunos } \\
\text { reflitam sobre as características do } \\
\text { gênero a partir das apresentações } \\
\text { anteriores. } \\
\text { Atividade } 2 \\
\text { Pede que os alunos escrevem a } \\
\text { definição do gênero infográfico. } \\
\text { Atividade } 3 \\
\text { Apresenta algumas definições do } \\
\text { gênero. } \\
\text { Atividade } 4 \\
\text { Traz o infográfico Education by the } \\
\text { numbers. Propõe atividade sobre o } \\
\text { layout do gênero, bem como sobre o } \\
\text { tema. } \\
\text { Atividade com enfoque nos numerais. } \\
\text { Atividades sobre a compreensão do } \\
\text { texto apresentado e sobre sua } \\
\text { organização. }\end{array}$ & $\begin{array}{l}\text { - Definição do gênero. } \\
\text { - Texto curto e objetivo. } \\
\text { - Relação entre os números, } \\
\text { as ilustrações e o texto } \\
\text { verbal. } \\
\text { - Organização do texto - } \\
\text { layout. } \\
\text { - Organização em tópicos, } \\
\text { subtópicos. de mapas, } \\
\text { - Presença de } \\
\text { porcentagens, gráficos. }\end{array}$ \\
\hline Produção escrita & $\begin{array}{l}\text { Produção escrita } \\
\text { Denominado de } \\
\text { Initial production - Part } 3 \\
\text { Apresenta orientações para a } \\
\text { produção do infográfico pelos alunos: } \\
\text { - Relação de temas } \\
\text { - Orientação para entrevista com os } \\
\text { possiveis participantes } \\
\text { - Lembretes gerais (equilibrio entre } \\
\text { imagens e informação, linguagem } \\
\text { concisa, palavras de impacto, } \\
\text { formatação/layout) }\end{array}$ & $\begin{array}{l}\text { - Tema } \\
\text { - Busca de fontes de } \\
\text { pesquisa } \\
\text { - Imagens } \\
\text { - Linguagem concisa } \\
\text { - Léxico } \\
\text { - Layout }\end{array}$ \\
\hline
\end{tabular}




\begin{tabular}{|c|c|c|}
\hline Módulo 3 & $\begin{array}{l}\text { Módulo } 3 \text { - Denominado de } \\
\text { Present Simple as a tool to write } \\
\text { infographics } \\
\text { Traz o infográfico Innovation in } \\
\text { Education } \\
\text { Atividade } 1 \\
\text { Enfoca o léxico e uso dos números } \\
\text { Traz o infográfico Technology in } \\
\text { Education } \\
\text { Atividade } 2 \\
\text { Compreensão do texto } \\
\text { Atividade } 3 \\
\text { Enfoque em pronomes pessoais e } \\
\text { verbos no tempo presente. } \\
\text { Atividade4 } \\
\text { Formalização da regra do presente } \\
\text { simples. } \\
\text { Busca de exemplos de uso do presente } \\
\text { simples nos infográficos apresentados,. }\end{array}$ & $\begin{array}{l}\text { - Tempo presente simples } \\
\text { - Tema } \\
\text { - Números }\end{array}$ \\
\hline Revisão e reescrita & $\begin{array}{l}\text { Revisão e reescrita - Denominado de } \\
\text { FeedBack and rewriting. } \\
\text { Solicita que os alunos analisem seu } \\
\text { texto corrigido pelo professor. } \\
\text { Presença de questões norteadores } \\
\text { para análise do texto. } \\
\text { Pede que os alunos reescrevam o } \\
\text { texto para ser compartilhado com a } \\
\text { turma posteriormente e também com } \\
\text { toda a escola. }\end{array}$ & $\begin{array}{l}\text { - Presença de informação } \\
\text { precisa. } \\
\text { - Objetividade na linguagem. } \\
\text { - Equilibrio entre imagem e } \\
\text { informação. } \\
\text { - Uso de cores e formas. } \\
\text { - Layout } \\
\text { - Texto atraente e } \\
\text { compreensivel. }\end{array}$ \\
\hline Módulo 4 & $\begin{array}{l}\text { Módulo } 4 \text { - Denominado de } \\
\text { American Classroom X Our Classroom } \\
\text { Traz o infográfico Wireless } \\
\text { Technology in the classroom. } \\
\text { Atividade } 1 \\
\text { Pede que os alunos analisem no } \\
\text { infográfico a presença das cores, dos } \\
\text { números, das imagens, a organização } \\
\text { do texto em tópicos. } \\
\text { Atividade } 2 \\
\text { Pede que os alunos traduzam } 3 \\
\text { informaçães retiradas do texto. A } \\
\text { partir disso, questiona sobre o tempo } \\
\text { verbal. } \\
\text { Pede que resumam as informações } \\
\text { do texto. } \\
\text { Solicita que escrevam sua opinião } \\
\text { sobre o uso da tecnologia em sala de } \\
\text { aula. }\end{array}$ & $\begin{array}{l}\text { - Tema } \\
\text { - Cores } \\
\text { - Números } \\
\text { - Imagens } \\
\text { - A organização do texto em } \\
\text { tópicos. } \\
\text { - Tempo presente simples }\end{array}$ \\
\hline Produção final & $\begin{array}{l}\text { Produção Final - Denominado de } \\
\text { Final production and sharing } \\
\text { - Solicita que os alunos analisem } \\
\text { novamente seus textos com base nas } \\
\text { anotações do professor. } \\
\text { - Pede que retornem as questões da } \\
\text { seção de reescrita para analisarem o } \\
\text { texto. } \\
\text { - Orienta que façam os ajustes } \\
\text { necessários para apresentar para a } \\
\text { classe. } \\
\text { - Indica aos alunos que posteriormente } \\
\text { os textos serão apresentados a } \\
\text { outros componentes da escola. }\end{array}$ & $\begin{array}{l}\text { - Layout } \\
\text { - Texto atraente } \\
\text { compreensível. }\end{array}$ \\
\hline
\end{tabular}


Fonte: a autora.

O que podemos perceber com relação à organização geral da SD é que, em sua primeira versão, ainda não havia o entendimento de uma proposta de escrita como processo a partir do gênero. O trabalho se encerrou com o módulo que tratava de questões linguísticas. Já a versão final apresentou todos os elementos da estrutura da SD.

Com relação aos elementos ensináveis do gênero, percebemos um enfoque no tema e, portanto, léxico voltado à temática. As características contextuais não foram contempladas, o que nos leva a inferir que as capacidades de ação e de significação não foram mobilizadas, ou foram muito pouco mobilizadas, tanto na primeira, quanto na última versão. Também deixaram de ser atendidas grande parte das características discursivas, tendo sido tratado da presença de frases curtas. Questões básicas como título, texto introdutório, indicação das fontes, assinatura dos autores não foram mencionadas. As características linguístico-discursivas foram mais contempladas nas atividades, tendo sido tratado sobre o tempo presente simples, o léxico, advérbios, números, porcentagem. Com relação às características multissemióticas, foram propostas atividades voltadas para análise de imagens, cores.

Embora possamos visualizar uma mudança significativa entre a primeira e a última versão da SD, ainda assim há muitos elementos que não foram tratados no material. Isso, com certeza, se deve a vários fatores. Não se pode deixar de considerar que a professora em questão não tinha conhecimento, ou tinha pouco conhecimento, dos pressupostos teóricos do ISD e de sua proposta de ensino com base no procedimento SD até o momento de sua participação no curso. Os quatro primeiros encontros do curso foi o que subsidiou esta primeira experiência da professora em elaborar uma SD. Apesar de, durante o curso, ter sido tratado sobre o MDG com os professores e, também, de ter sido solicitado a eles que elaborassem um MDG sobre o gênero que iria conduzir a SD, temos ciência de que não houve tempo hábil para que tais atividades fossem desenvolvidas a contento. O que nos remete à afirmação já feita por nós de que a existência de um MTG seria de grande ajuda na elaboração do MDG e da SD. 


\section{Algumas Considerações}

Diante das análises aqui apresentadas, temos que o agir impulsionador da realização deste estudo constituiu-se em uma ação de elaboração de uma SD com foco no gênero de texto infográfico, por parte de uma professora de língua inglesa ao participar de uma atividade voltada a um processo de formação continuada. A ação de elaboração da referida SD pode vir a ser interpretada e compreendida mediante o agir da professora como um ator, que se vê envolto por determinantes externos, instrumentos, finalidades (visto tratar-se de um agir que envolve também o contexto coletivo de atuação da professora); motivos, capacidades e intenções (visto tratar-se de um agir específico dessa mesma professora quando faz suas próprias escolhas para elaboração da SD e até mesmo para a participação na SF). Tendo sido todos esses aspectos, reguladores assim como regulados, em maior ou menor grau, das/pelas ações linguageiras, bem como das não linguageiras (gerais) da professora foco deste estudo.

Ao participar da atividade proposta como sendo um curso de formação continuada, a professora esteve inserida em um coletivo, o qual envolvia outros colegas de profissão, pertencentes a outras escolas/municípios. Todo esse conjunto de professores esteve envolvido em uma atividade coletiva - a participação no curso de formação. Assim, as atividades desenvolvidas por este coletivo foram impulsionadas, no plano motivacional, por determinantes externos, vinculados tanto à natureza material quanto à ordem das representações. No plano intencional, vincularam-se a finalidades validadas socialmente. No plano dos recursos para o agir, as atividades se concretizaram a partir de instrumentos vários disponíveis no meio social e trazidos ao grupo durante seus encontros de formação.

Apesar de estarem inseridos em um coletivo, realizando atividades a partir de e com um coletivo, cada um dos professores participantes era também um 
actante individual, realizando, portanto, a sua ação dentro da atividade e, por sua vez, envolvendo fatores únicos a impulsionar seu agir.

Com relação à professora foco deste estudo e, não deixando de considerar os possíveis fatores que impulsionaram e/ou dificultaram seu agir, as análises demonstraram que ela foi capaz de realizar a transposição didática externa do gênero de texto infográfico e de seus elementos ensináveis, ainda que de forma parcial, conforme demonstrado no Quadro 6, em comparação ao que se apresenta no Quadro 5.

Com relação ao MTG apresentado no Quadro 4, entendemos que caberá a cada professor, em sua realidade de atuação, determinar quais elementos serão mais adequados a seu contexto de ensino, a depender sempre dos objetivos propostos e do nível de desenvolvimento real apresentado pela turma. Daí a importância de o professor ter como subsídio de preparação de suas aulas o MTG com o qual irá trabalhar. É, sem dúvida, um elemento facilitador do trabalho do professor que se vê envolto em tantas condições de trabalho desfavoráveis.

Finalmente, ao buscarmos uma reflexão sobre as possibilidades de desenvolvimento da professora em questão, afirmamos, ainda que de uma forma preliminar, que a docente passou por situações propiciadoras de novas zonas de desenvolvimento proximal. A forma de organização da SD em sua primeira versão comparativamente à versão final, dão indícios de que tenha havido um deslocamento de uma zona de desenvolvimento real para uma nova zona de desenvolvimento proximal. Mas, temos consciência de que há ainda muito a ser trabalhado, pois acreditamos que as apropriações, o desenvolvimento, acontecem em um processo que nunca se encerra e que se forma a partir de inter-relações sócio-histórico-culturais, que são coletivas e, ao mesmo tempo, particulares e específicas, de acordo com os motivos e o envolvimento de cada um dos agentes. Estaríamos, nesse momento, vislumbrando apenas o que poderia vir a se constituir o início de um processo de desenvolvimento. Necessitando outras formas de agir que viessem a dar continuidade ao que se iniciou com esse processo de elaboração de SD com base em gênero de texto. 
A SF proposta por nós, em certa medida, visa propiciar algumas outras formas de agir com vistas a esse processo de desenvolvimento docente. A ação de implementação da SD produzida, as sessões de autoconfrontação simples e cruzada e, finalmente, a extensão ao coletivo seriam essas outras formas.

Contudo, a nossa convicção é a de que um processo de formação continuada que, de fato, busque o desenvolvimento dos professores participantes, necessita, acima de tudo, se constituir como um continuum de agires que se organizam a partir do entendimento de que escola necessita de profissionais que se percebam e que ajam como atores sociais, assumindo uma postura transformadora de seu contexto de atuação. Para tanto, defendemos a necessidade de fortalecer o coletivo, e assim cada um dos agentes, por meio de formação de grupos permanentes de formação continuada, a que denominamos de sequência de formação.

\section{Referências}

AL HOSNI, Jokha. The power of image in English language teaching. The Journal of Teaching English for Specific and Academic Purposes, Serbia, v. 4, n. 1, p. 229, 2016. Disponível em:

http://espeap.junis.ni.ac.rs/index.php/espeap/article/view/320. Acesso em: 15 ago. 2018.

ASSUNÇÃO, Fábio Nunes. Estratégias de leitura em língua inglesa: um estudo de infográficos em uma perspectiva multimodal. 2014. 156 f. Dissertação (Mestrado em Linguística Aplicada) - Programa de Pós-Graduação em Linguística Aplicada, Universidade Estadual do Ceará, Fortaleza, 2014. Disponível em: www.uece.br/posla/dmdocuments/FÁBIO\%20NUNES\%20ASSUNÇÃO.pdf. Acesso em: 15 ago. 2018.

BARROS, Eliana Merlin Deganutti. Gestos de ensinar e de aprender gêneros textuais: a sequência didática como instrumento de mediação. 2012. Tese (Doutorado em Estudos da Linguagem) - Universidade Estadual de Londrina, Centro de Letras e Ciências Humanas, Programa de Pós-Graduação em Estudos da Linguagem, Londrina, 2012. Disponível em: http://www.bibliotecadigital.uel.br/document/?code=vtls000171939. Acesso em: 3 fev. 2015. 
BRONCKART, Jean-Paul. Atividade de linguagem, textos e discursos. por um interacionismo sócio-discursivo. Tradução de Anna Rachel Machado e Péricles Cunha. 2. ed. São Paulo: EDUC, 2007.

BRONCKART, Jean-Paul. Atividade de linguagem, textos e discursos. por um interacionismo sócio-discursivo. Tradução de Anna Raquel Machado e Péricles Cunha. São Paulo: EDUC, Ed. 2, 2012.

BRONCKART, Jean-Paul. Interacionismo sócio-discursivo: uma entrevista com Jean Paul Bronckart. Tradução de Cassiano Ricardo Haag e Gabriel de Ávila Othero. Revista Virtual de Estudos da Linguagem-ReVEL, [S. I.], v. 4, n. 6, mar. 2006. Disponível em:

http://www.revel.inf.br/files/entrevistas/revel_6_entrevista_bronckart_port.pdf. Acesso em: 14 out. 2013.

BRONCKART, Jean-Paul. $O$ agir nos discursos. das concepções teóricas às concepções dos trabalhadores. Tradução de Anna Rachel Machado e Maria de Lourdes Meirelles Matencio. Campinas: Mercado das Letras, 2008.

BRONCKART, Jean-Paul. Um retorno necessário à questão do desenvolvimento. In: BUENO, Luzia; LOPES, Maria Ângela Paulino Teixeira; CRISTÓVÃO, Vera Lúcia Lopes (org.). Gêneros textuais e formação inicial: uma homenagem à Malu Matêncio. Campinas: Mercado de Letras, 2013. p. 85-107.

CHEVALLARD, Yves. On didactic transposition theory: some introductory notes. 1989. Disponível em:

http://yves.chevallard.free.fr/spip/spip/rubrique.php3?id_rubrique=6. Acesso em: 17 jan. 2015.

CRISTOVÃO, Vera Lúcia Lopes. Modelos didáticos de gênero: uma abordagem para o ensino de língua estrangeira. Londrina: UEL, 2007.

CRISTOVÃO, Vera Lúcia Lopes. Para uma expansão do conceito de capacidades de linguagem. In: BUENO, Luzia; LOPES, Maria Angela Paulino Teixeira; CRISTOVÃO, Vera Lúcia Lopes (org.). Gêneros textuais e formação inicial:homenagem à Malu Matencio. Campinas: Mercado de Letras, 2013. p. 357-383.

CRISTOVÃO, Vera Lúcia Lopes. Uma proposta de planejamento de ensino de língua inglesa em torno de gêneros textuais. Letras, Santa Maria, v. 20, n. 40, p. 191-215, jan./jun. 2010. Disponível em:

http://w3.ufsm.br/revistaletras/artigos_r40/artigo_11.pdf. Acesso em: 13 set. 2013.

CRISTOVÃO, Vera Lúcia Lopes; STUTZ, Lidia. Sequências didáticas: semelhanças e especificidades no contexto francófono como L1 no contexto 
brasileiro como LE. In: SZUNDY, Paula Tatianne Carréra; ARAUJO, Júlio Cezar; NICOLAIDES, Christiane Siqueira; SILVA, Kleber Aparecido (org.). Linguística aplicada e sociedade. ensino e aprendizagem de línguas no contexto brasileiro. Campinas: Pontes Editores, 2011.

DIONÍSIO, Angela Paiva (org.). Verbetes enciclopédicos. gráfico e infográfico. Recife: Pipa Comunicação, 2013. Disponível em: http://pibidletras.com.br/serieverbetes/serie-verbetes-enciclopedicos-volume4-grafico-e-infografico.pdf. Acesso em: 30 jul. 2018.

DOLZ, Joaquim. Os cincos novos desafios para o ensino da Língua Portuguesa: parte 2. In: SEMINÁRIO INTERNACIONAL ESCREVENDO O FUTURO, 2015, São Paulo. Palestra proferida... São Paulo: Espaço APAS, 2015. 1 vídeo (43:05 min). Disponível em: https://www.youtube.com/watch?v=Gps1x4tmFwk. Acesso em: 21 ago. 2018.

DOLZ, Joaquim; NOVERRAZ, Michele; SCHNEUWLY, Bernard. Sequencias didáticas para o oral e a escrita: apresentação de um procedimento. In: SCHNEUWLY, Bernard; DOLZ, Joaquim. Gêneros orais e escritos na escola. Campinas: Mercado de Letras, Ed.2, 2010.

DOLZ, Joaquim; SCHNEUWLY, Bernard. Gêneros e progressão em expressão oral e escrita: elementos para reflexões sobre uma experiência suíça (francófona). In: SCHNEUWLY, Bernard; DOLZ, Joaquim. Gêneros orais e escritos na escola. Campinas: Mercado de Letras, Ed.2, 2010. p. 44-64.

GONÇALVES, Letícia Aparecida de Araújo; ROSOLEM, Loretta Derbli Durães da Luz. Infográfico: uma proposta de modelo didático do gênero. In: CRISTOVÃO, Vera Lúcia Lopes (org.). Gêneros: (textuais /discursivos), ensino e educação (inicial e continuada) de professores de línguas. Campinas, Mercado de Letras, 2018. p. 541-558.

KANNO, Mário. Infográfico: como e porque usar infográficos para criar visualizações e comunicar de forma imediata e eficiente. Edição eletrônica. São Paulo: Infolide, 2013. Disponível em:

https://designlyn.files.wordpress.com/2014/06/infografemariokannopagsimples130822154840-phpapp02.pdf. Acesso em: 26 ago. 2018.

LENHARO, Rayane Isadora. Participação social por meio da música e da aprendizagem de língua inglesa em um contexto de vulnerabilidade social. 2016. 148 f. Dissertação (Mestrado em Estudos da Linguagem) - Universidade Estadual de Londrina, Londrina, 2016.

MACHADO, Anna Rachel. A perspectiva interacionista sociodiscursiva de Bronckart. In: MEURER, José Luiz; BONINI, Adair; MOTTA-ROTH, Désirée 
(org.). Gêneros: teorias, métodos, debates. São Paulo: Parábolas Editorial, 2005. p. 237-259.

MACHADO, Anna Rachel; CRISTOVÃO, Vera Lúcia Lopes. A construção de modelos didáticos de gêneros: aportes e questionamentos para o ensino de gêneros. Linguagem em (Dis)curso, Tubarão, v. 6, n. 3, p. 547-573, set./dez. 2006. Disponível em http://linguagem.unisul.br/paginas/ensino/pos/linguagem/linguagem-emdiscurso/0603/060309.pdf. Acesso em: 15 out. 2014.

NASCIMENTO, Elvira Lopes. Práticas de letramento, gênero e interação social: o saber e o fazer dos professores do ensino fundamental. In: COLÓQUIO INTERNACIONAL DE ESTUDOS LINGUÍSTICOS ELITERÁRIOS - CIELLI, 1., 2010, Maringá. Anais [...]. Maringá: UEM, PLE, 2010. Disponível em: http://anais.cielli.com.br/artigos. Acesso em: 12 fev. 2015.

OLIVEIRA, Marta Kohl. A mediação simbólica; o uso de instrumentos, o uso de signos e o processo de internalização. In: OLIVEIRA, Marta Kohl. Vygotsky. aprendizado e desenvolvimento, um processo sócio-histórico. São Paulo: Scipione, 1997.

PONTARA, Claudia Lopes; CRISTOVÃO, Vera Lucia Lopes. Sequência de formação para professores de língua inglesa: estabelecendo relações com os saberes e capacidades docentes. Signum; estudos da linguagem, Londrina, v. 21, n. 2, 2018.

SCHNEUWLY, Bernard; DOLZ, Joaquim. Gêneros orais e escritos na escola. Campinas: Mercado das Letras, 2010.

STETSENKO, Anna. The transformative mind: expanding Vygotsky's perspective on development and education. New York: Cambridge University Press, 2016.

STUTZ, Lidia. Sequências didáticas, socialização de diários e autoconfrontação: instrumentos para a formação inicial de professores de inglês. 2012. Tese (Doutorado em Estudos da Linguagem) - Universidade Estadual de Londrina, Londrina, 2012. Disponível em:

http://www.bibliotecadigital.uel.br/document/?code=vtls000178953. Acesso em: 13 jan. 2015.

TEIXEIRA, Tattiana. Infografia e jornalismo: conceitos, análises e perspectivas. Salvador: EDUFBA, 2010. Disponível em: https://repositorio.ufba.br/ri/handle/ri/20642. Acesso em: 2 ago. 2018.

VIANNA, Eduardo; STETSENKO, Anna. Embracing history through transforming it: contrasting Piagetian versus Vygotskian (activity) theories of learning and development to expand constructivism within a dialectical view of history. 
Theory \& Psychology, London, v. 16, n. 1, p. 81-108, 2006. Disponível em: https://doi.org/10.1177/0959354306060108. Acesso em: 22 jan. 2019.

VYGOTSKY, Lev Semenovich. Mind in society: the development of higher psychological processes. Cambridge: Harvard University Press, 1978. 